Nevada

Environmental

Restoration

Project

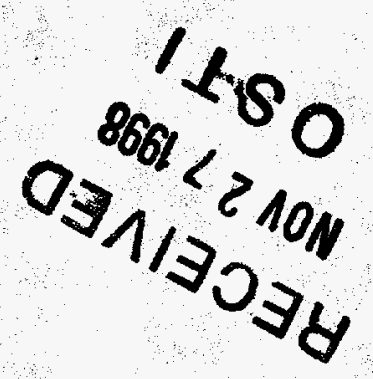

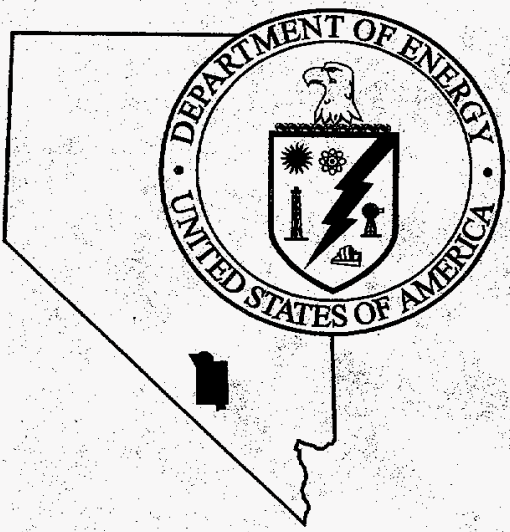

Streamlined Approach for

Environmental Restoration

Closure Report for

Corrective Action Unit 464:

Historical Underground Storage

Tank Release Sites,

Nevada Test Site, Nevada

Controlled Copy No.:

Revision: 0

DSTRBUTION OF THS DOCUMENT IS UNUMUTED

April 1998

MASTER

Approved for public release; further distribution is authorized

Environmental Restoration

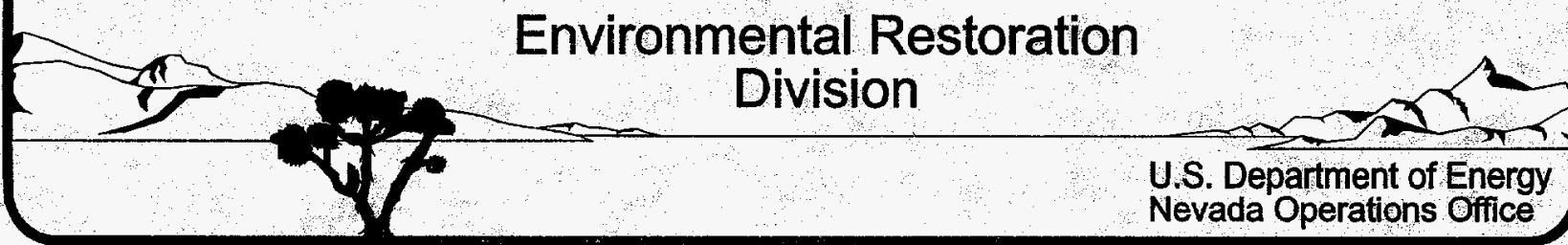


This report has been reproduced from the best available copy.

DOE and DOE contractors can obtain copies of this report from the Office of Scientific and Technical Information, P.O. Box 62, Oak Ridge, TN 37831, (423) 576-8401.

This report is publicly available from the National Technical Information Service, U. S: Department of Commerce, 5285 Port Royal Road, Springfield, VA 22161, (703) 487-4650. 


\section{DISCLAIMER}

This report was prepared as an account of work sponsored by an agency of the United States Government. Neither the United States Government nor any agency thereof, nor any of their employees, makes any warranty, express or implied, or assumes any legal liability or responsibility for the accuracy, completeness, or usefulness of any information, apparatus, product, or process disclosed, or represents that its use would not infringe privately owned rights. Reference herein to any specific commercial product, process, or service by trade name, trademark, manufacturer, or otherwise does not necessarily constitute or imply its endorsement, recommendation, or favoring by the United States Government or any agency thereof. The views and opinions of authors expressed herein do not necessarily state or reflect those of the United States Government or any agency thereof. 


\section{DISCLAIMER}

Portions of this document may be illegible in electronic image products. Images are produced from the best available original document. 


\title{
STREAMLINED APPROACH FOR ENVIRONMENTAL RESTORATION CLOSURE REPORT FOR CORRECTIVE ACTION UNIT 464 HISTORICAL UNDERGROUND STORAGE TANK RELEASE SITES, NEVADA TEST SITE, NEVADA
}

\author{
Prepared for \\ U. S. Department of Energy \\ Nevada Operations Office \\ Under Contract No. DE-AC08-96NV11718 \\ Controlled Copy No.: \\ Revision: 0 \\ Prepared by \\ Bechtel Nevada \\ Environmental Restoration
}

April 1998 


\section{STREAMLINED APPROACH FOR ENVIRONMENTAL RESTORATION CLOSURE REPORT FOR \\ CORRECTIVE ACTION UNIT 464 HISTORICAL UNDERGROUND STORAGE TANK RELEASE SITES, NEVADA TEST SITE, NEVADA}

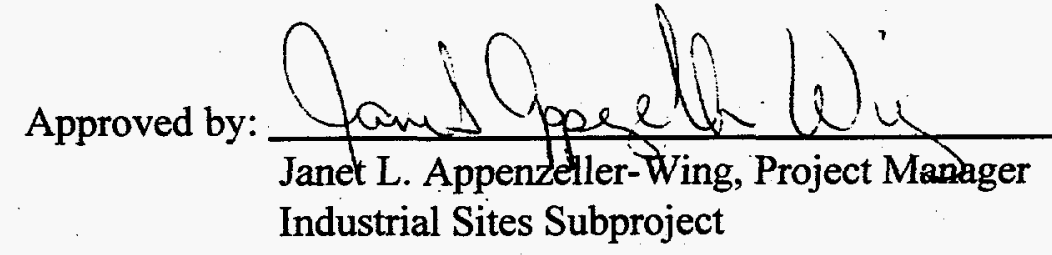

Approved by: OLotent an. Bangunter en.

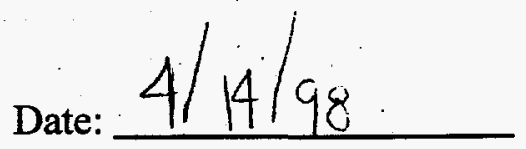

Date: 


\section{TABLE OF CONTENTS}

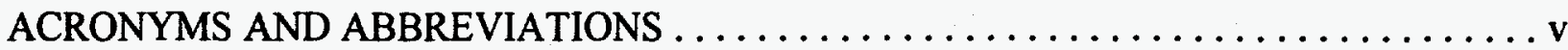

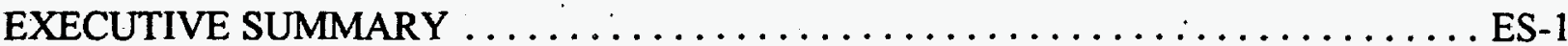

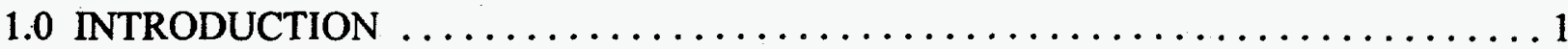

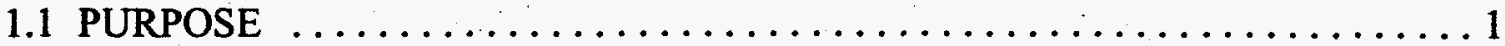

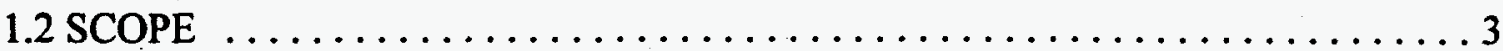

1.3 CLOSURE REPORT CONTENTS $\ldots \ldots \ldots \ldots \ldots \ldots \ldots \ldots \ldots \ldots \ldots \ldots \ldots$

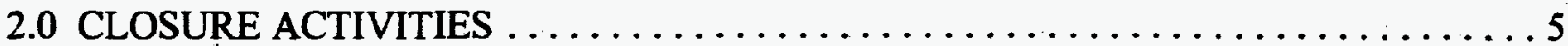

2.1 DESCRIPTION OF CORRECTIVE ACTION ACTIVITIES $\ldots \ldots \ldots \ldots \ldots \ldots 5$

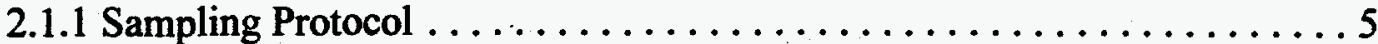

2.1.2 Description and Background: Release Site $2-300-1 \ldots \ldots \ldots \ldots 6$

2.1.2.1 Drilling Activities: Release Site $2-300-1 \ldots \ldots \ldots \ldots \ldots 6$

2.1.3 Description and Background: Release Site $9-300-1 \ldots \ldots \ldots \ldots \ldots .8$

2.1.3.1 Excavation Activities: Release Site $9-300-1 \ldots \ldots \ldots \ldots .88$

2.2 DEVIATIONS FROM THE SAFER WORK PLAN $\ldots \ldots \ldots \ldots \ldots \ldots \ldots ., \ldots$

2.3 CORRECTIVE ACTION SCHEDULE AS COMPLETED $\ldots \ldots \ldots \ldots \ldots 10$

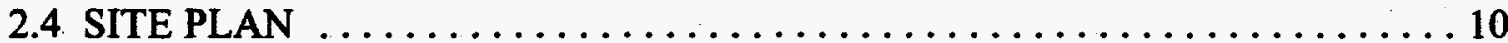

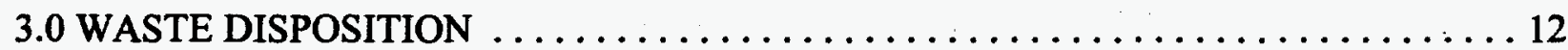

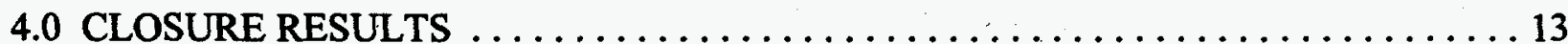

4.1 RELEASE SITE 2-300-1 (CAS 02-02-03) $\ldots \ldots \ldots \ldots \ldots \ldots \ldots \ldots \ldots \ldots$

4.1.1 A Through K Evaluation: UST Release Site $2-300-1 \ldots \ldots \ldots \ldots \ldots 13$

4.2 RELEASE SITE 9-300-1 (CAS 09-02-01) .................. 17

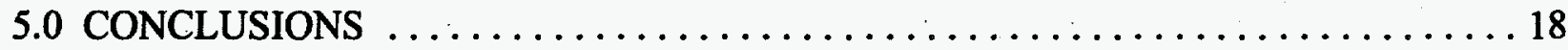

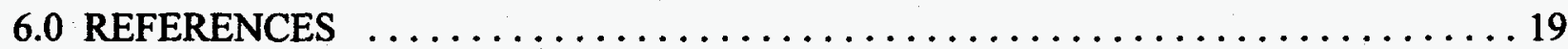

APPENDIX A - UST CLOSURE INFORMATION

APPENDIX B - DISPOSAL DOCUMENTATION

APPENDIX C - 2-300 BOREHOLE LOGS

APPENDIX D - LABORATORY ANALYTICAL DATA 


\section{TABLE OF CONTENTS (continued)}

\section{FIGURES}

FIGURE 1 - SITE LOCATION MAP CAU $464 \ldots \ldots \ldots \ldots \ldots \ldots \ldots \ldots \ldots \ldots$

FIGURE 2 - BUNKER 2-300 SITE LAYOUT AND BOREHOLE LOCATIONS $\ldots \ldots \ldots \ldots 7$

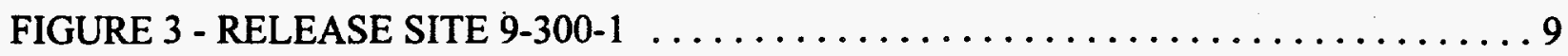

FIGURE 4 - CAU 464 SITE CHARACTERIZATION ACTIVITY SCHEDULE . . . . . . 11

\section{TABLES}

TABLE 1 - CAU 464 HYDROCARBON RELEASE SITES $\ldots \ldots \ldots \ldots \ldots \ldots \ldots \ldots \ldots \ldots$

TABLE 2 - DRILL SITE 2-300-1: SUMMARY OF SOIL ANALYTICAL RESULTS . . . 14 


\section{ACRONYMS AND ABBREVIATIONS}

bgs below ground surface

CAS Corrective Action Site

CAU Corrective Action Unit

cm centimeter

CR Closure Report

DOE/NV U.S. Department of Energy, Nevada Operations Office

EPA U.S. Environmental Protection Agency

FFACO Federal Facility Agreement and Consent Order

$\mathrm{ft} \quad$ feet

gal gallons

in inches

km kilometers

L liters

m meters

$\mathrm{m}^{3} \quad$ cubic meters

MDL method detection limit

$\mathrm{mg} / \mathrm{kg} \quad$ milligrams per kilogram

mi mile

ml milliliters

NAC Nevada Administrative Code 


\section{ACRONYMS AND ABBREVIATIONS (continued)}

$\begin{array}{ll}\text { NDEM } & \text { Nevada Division of Environmental Management } \\ \text { NDEP } & \text { Nevada Division of Environmental Protection } \\ \text { NEL } & \text { Nevada Environmental Laboratories } \\ \text { NTS } & \text { Nevada Test Site } \\ \text { OVM } & \text { Organic Vapor Monitor } \\ \text { ppm } & \text { parts per million } \\ \text { SAFER } & \text { Streamlined Approach for Environmental Restoration } \\ \text { TPH } & \text { Total Petroleum Hydrocarbon } \\ \text { UST } & \text { Underground Storage Tank } \\ \text { VOC } & \text { Volatile Organic Compound } \\ \text { yd } & \text { cubic yards }\end{array}$


This report addresses the site characterization of two historical underground storage tank petroleum hydrocarbon release sites identified by Corrective Action Site (CAS) Numbers 02-0203 and 09-02-01. The sites are located at the Nevada Test Site in Areas 2 and 9 and are concrete bunker complexes (Bunker 2-300, and 9-300). The sites are listed in the Federal Facility Agreement and Consent Order (FFACO) in Appendix III and are the only two sites in Corrective Action Unit (CAU) 464. Work was completed following the Nevada Division of Environmental Protection-approved document, Streamlined Approach for Environmental Restoration Work Plan for CAUs 452, 454, 456, and 464. Closure of Historical UST Release Sites.

Characterization was completed using drilling equipment to delineate the extent of petroleum hydrocarbons at release site 2-300-1 (CAS 02-02-03). Based on site observations, the low hydrocarbon concentrations detected, and the delineation of the vertical and lateral extent of subsurface hydrocarbons, an "A through K" evaluation was completed to support a request for an Administrative Closure of the site.

Clean closure was completed using a backhoe at release site 9-300-1 (CAS 09-02-01). The verification sample collected at approximately 3.0 meters ( $10 \mathrm{feet}$ ) below the location of the former tank south bottom did not contain diesel above the method detection limit $(<10$ milligrams per kilogram).

Based upon site observations and the soil sample analytical results it is requested that a Notice of Completion be provided by the Nevada Division of Environmental Protection. Upon closure approval, CAU 456 will be promoted from Appendix III to Appendix IV of the FFACO "Closed Corrective Action Units." 


\subsection{INTRODUCTION}

This report addresses the site characterization of two historical underground storage tank (UST) petroleum hydrocarbon release sites. The sites are identified as Bunkers 2-300-1 and 9-300-1 and are located at the Nevada Test Site (NTS) in Areas 2 and 9, respectively (Table 1, Figure 1). These two sites are listed in the Federal Facility Agreement and Consent Order (FFACO) in Appendix III and comprise Corrective Action Unit (CAU) 464 (FFACO, 1996). The hydrocarbon releases associated with former tank sites 2-300-1 and 9-300-1 have been assigned Corrective Action Site (CAS) Numbers 02-02-03 and CAS 09-02-01, respectively. The USTs identified in this report were closed by removal in 1996 by the U.S. Department of Energy, Nevada Operations Office (DOE/NV). Subsequent to tank closure the Nevada Division of Environmental Protection (NDEP) was provided amended Environmental Protection Agency (EPA) Forms 7530-1 (Notification for USTs), in addition to tank closure information and analytical data. Tank closure information is provided in Appendix A:

\section{TABLE 1 - CAU 464 HYDROCARBON RELEASE SITES}

\begin{tabular}{|c|c|c|c|c|c|}
\hline $\begin{array}{l}\text { UST } \\
\text { ID }^{1}\end{array}$ & $\begin{array}{c}\text { UST } \\
\text { CAS } \\
\text { NUMBER }^{2}\end{array}$ & $\begin{array}{l}\text { RELEASE } \\
\text { CAS } \\
\text { NUMBER }^{3}\end{array}$ & $\begin{array}{c}\text { NDEM } \\
\text { NUMBER }\end{array}$ & LOCATION & $\begin{array}{c}\text { DATE } \\
\text { REMOVED/ } \\
\text { CLOSED }^{\text {S }}\end{array}$ \\
\hline $2-300-1$ & $02-02-03$ & $02-02-03$ & $960603-771$ & Area 2-300 Bunker & April 30, 1996 \\
\hline $9-300-1$ & $09-02-01$ & $09-02-01$ & $960701-849$ & Area 9-300 Bunker & May 2, 1996 \\
\hline
\end{tabular}

Notes:

${ }^{1}$ Underground Storage Tank Identification Number.

${ }^{2}$ Corrective Action Site Number assigned to the UST within the FFACO.

${ }^{3}$ Corrective Action Site Number assigned to the hydrocarbon release within the FFACO.

${ }^{4}$ Nevada Division of Environmental Management Number assigned at time of release identification.

${ }^{5}$ Date which tank was closed by removal.

\subsection{PURPOSE}

Hydrocarbon releases were identified at each of the two sites based upon laboratory analytical data collected at the time of tank closures. Hydrocarbon concentrations at these sites exceeded the Nevada Administrative Code (NAC) Action Level of 100 milligrams per kilogram (mg/kg) (NAC 459.9973, 1996). NDEP requires assessment and corrective actions for soil with a petroleum hydrocarbon concentration exceeding the NAC Action Level. Each release was assigned a Nevada Division of Emergency Management (NDEM) number at the time of spill notification (Table 1). 
Date: April 22, 1998

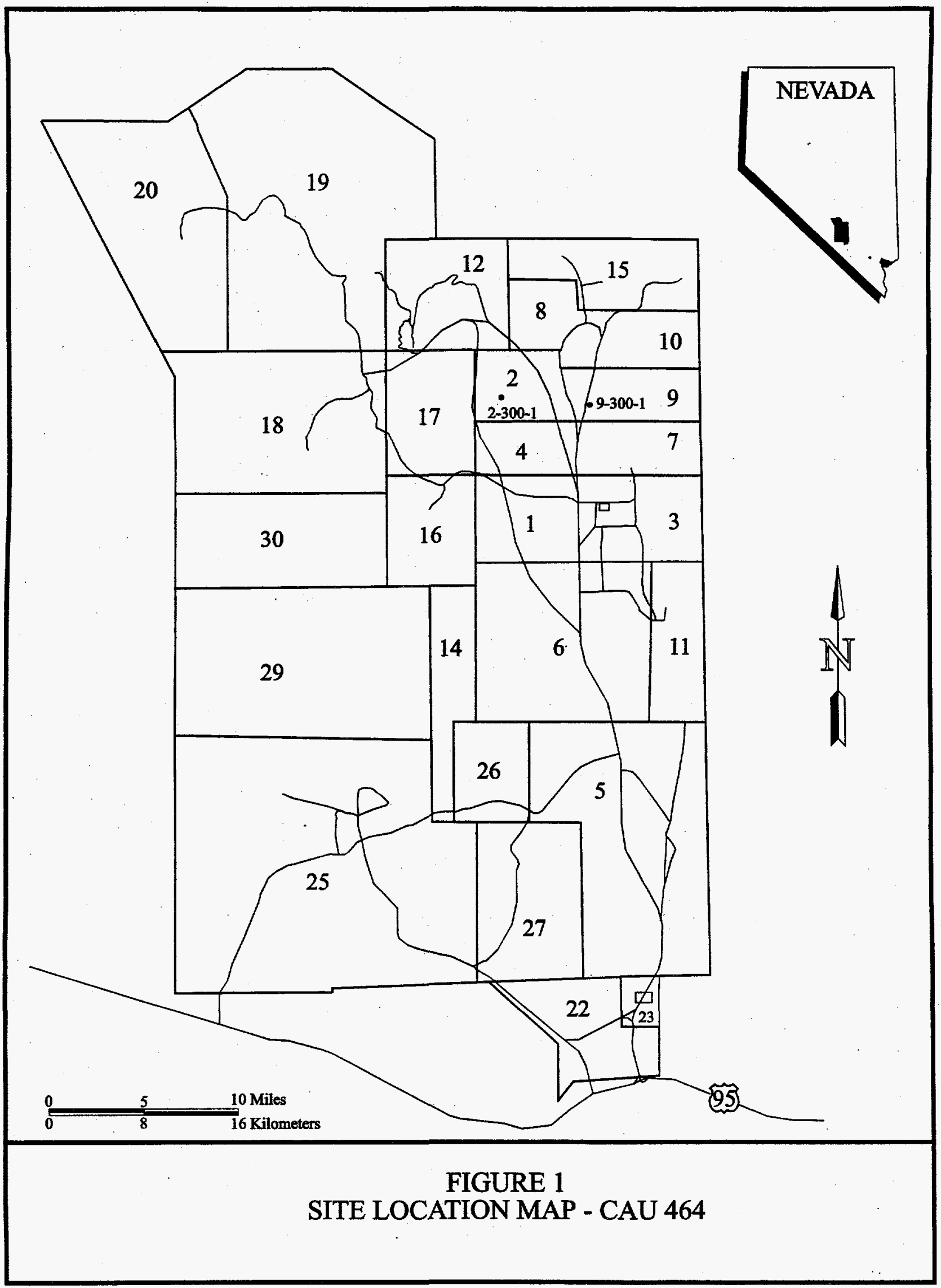


The purpose of this Closure Report (CR) is to provide documentation of the activities completed during the characterization or remediation of the two hydrocarbon release sites. The work was completed as outlined in the Streamlined Approach for Environmental Restoration (SAFER) Work Plan for CAUs 452, 454, 456, and 464, Closure of Historical UST Release Sites (US DOE, 1997). The documentation provided in this CR supports a request to NDEP for closure of CAU 464.

\subsection{SCOPE}

The scope of work for CAS 02-02-03 (2-300-1) was to collect soil samples in an effort to identify the lateral and vertical extent of the hydrocarbon plume. The characterization was completed using a Mobil Drill B-59 continuous flight, hollow-stem auger drill rig. Drilling was required at this site due to the depth of petroleum hydrocarbons and proximity to the concrete 2300 bunker complex. Three boreholes were drilled at the site to sufficiently delineate the extent of the hydrocarbon plume. Data collected from the characterization activities is provided in this report to support Administrative Closure of the release site.

The scope of work for CAS 09-02-01 (9-300-1) was to over excavate hydrocarbon-impacted soil from the southern end of the former tank location where hydrocarbons were identified at the time of tank closure. One verification soil sample was collected from the bottom of the southern end of the excavation.

\subsection{CLOSURE REPORT CONTENTS}

This CR has been developed to support administrative closures of CAS 02-02-03 and the clean closure of CAS 09-02-01. The format of the report is as follows:

- Section 1.0 - Introduction, Purpose, and Scope.

- Section 2.0 - Closure Activities.

- Section 3.0 - Waste Disposition.

- Section 4.0 - Closure Results (including the "A through K" Evaluation).

- Section 5.0 - Conclusions.

- Section 6.0 - References.

- Appendix A - UST Closure Information. 
- Appendix B - Waste Disposal Documentation.

- Appendix C - 2-300 Borehole Logs.

- Appendix D - Laboratory Analytical Data.

The SAFER Work Plan was implemented using information and guidance provided from the following documents:

- SAFER Work Plan for CAUs $452,454,456$, and 464 Closure of Historical UST Release Sites, Nevada Test Site (US DOE, 1997).

- Site Specific Health and Safety Plan for SAFER Closure of Historical UST Release Sites Areas 2, 9, 12, 23, and 25 (BN, 1997a).

- Field Management Plan: CAU 452, 454, 456, and 464 Closure of Historical UST Release Sites. Nevada Test Site (BN, 1997b).

- Closure of Historical UST Release Sites, Construction Work Plan (BN, 1997c).

- Nevada Environmental Restoration Project, Project Management Plan (US DOE, 1994).

- Nevada Environmental Restoration Project. Health and Safety Plan (US DOE, 1996a).

- Nevada Environmental Restoration Project. Industrial Sites, Quality Assurance Project Plan. Nevada Test Site (US DOE, 1996b). 


\subsection{CLOSURE ACTIVITIES}

\subsection{DESCRIPTION OF CORRECTIVE ACTION ACTIVITIES}

\subsubsection{Sampling Protocol}

The CAU 464 sites were characterized to obtain data to support either an Administrative Closure (Bunker 2-300, CAS 02-02-03) or clean closure (Bunker 9-300, CAS 09-02-01). Prior to drilling at the 2-300 release site and excavating at the 9-300 release site, each site was cleared for underground utilities (Goldak) and signed excavation permits were issued. Boreholes drilled at the 2-300 release site were completed using continuous flight, hollow-stem auger drilling equipment. A backhoe was used to complete excavation activities at the 9-300 release site. Prior to each sampling event, sample equipment was decontaminated using Alconox cleaning solution and rinsed with distilled water. Augers were decontaminated using Alconox cleaning solution followed by a high pressure water rinse.

Soil samples for logging and chemical analysis from the 2-300 release site were collected at approximate 1.5-meter (m) (5-foot [ft]) intervals by advancing a split-spoon sampler, equipped with brass liners, into the undisturbed soil beyond the tip of the cutting head. If a sufficient volume of soil was recovered in the split-spoon, the bottom brass sleeve was retained, sealed with plastic end caps, and submitted to the off-site laboratory for analysis. If sufficient soil volume was not retained, the sample was placed into a clean 250-milliliter (ml) glass laboratory sample jar. The sample from the 9-300 release site was collected using the backhoe bucket and placed into a $250-\mathrm{ml}$ glass laboratory jar using a stainless steel scoop. All samples were labeled with the sample identification, date and time sampled, sampler's initials, and analysis to be performed. Samples were placed in a ice chest and cooled to approximately 4 degrees Centigrade (39.2 degrees Fahrenheit). Samples were kept in the custody of the project geologist or in a secured location until delivered to Nevada Environmental Laboratories (NEL) located in Las Vegas, Nevada.

Soil samples collected from each site were screened in the field using a Dexsil PetroFLAG ${ }^{\mathrm{Tm}}$ hydrocarbon analyzer kit. PetroFLAG ${ }^{\mathrm{TM}}$ screens for the presence of hydrocarbons to a concentration level of greater than (>)2,000 parts per million (ppm). Samples were also screened using an Organic Vapor Monitoring (OVM) Model 580B calibrated to $100 \mathrm{ppm}$ Isobutylene at the beginning of each field day.

At the 2-300 release site, if hydrocarbons were detected in the screened samples, the boreholes. were advanced until field screening indicated a PetroFLAG ${ }^{\mathrm{TM}}$ result of $<50 \mathrm{ppm}$. One to two screened samples which indicated the presence of hydrocarbons and the two subsequent confirmatory "clean" samples were then submitted to an off-site laboratory. Once the vertical extent of the release was defined, then the borehole locations were stepped out to define the lateral extent of impacted soil following the same screening process. The distance that each 
borehole was stepped out was contingent on drill rig access and the estimated vertical depth of the hydrocarbon plume.

\subsubsection{Description and Background: Release Site 2-300-1}

UST 2-300-1 was located on the east side of Bunker 2-300 within the Area 2 2-300 Bunker Complex (Figure 2). The tank had an approximate capacity of 1,900 liters (L) (500 gallons [gal]) and supplied diesel fuel for generators. The tank was full at the time of the initial field identification. One soil sample collected below the south tank bottom, at the time of tank removal on April 30, 1996, had a total petroleum hydrocarbon (TPH) concentration of 230 $\mathrm{mg} / \mathrm{kg}$. Analytical results from subsequent soil sampling on May 23, 1996, had a TPH concentration of $9,600 \mathrm{mg} / \mathrm{kg}$ at a depth of approximately $2.7 \mathrm{~m}(9 \mathrm{ft})$ below ground surface (bgs). The excavation activities in 1996 indicated that the spill had impacted soil under the generator room and access driveway. It is believed that the release was a result of historical periodic product line leakage. This is based upon the tank being full at the time of initial field identification, no soil staining observed above or directly below the tank at the time of closure, and no apparent holes or rust observed on the tank. Drilling was required at this site due to the following site limitations:

- Equipment access is limited by the sloped narrow driveway of the bunker complex.

- The former tank location is bordered on the west by the Bunker 2-300 generator room and is below a graded 1:1 sloped soil cover.

- The depth of hydrocarbon-impacted soil extends below the reach of excavation equipment.

Closure of the hydrocarbon release (NDEM No. 960603-771, CAS No. 02-02-03) is addressed in this report.

\subsubsection{Drilling Activities: Release Site 2-300-1}

Three boreholes were completed at this site (2-300-B1 through 2-300-B3). Borehole locations are shown on Figure 2. Borehole B1 was located approximately $2.5 \mathrm{~m}(8 \mathrm{ft})$ from the release area and was completed to a depth of $9.5 \mathrm{~m}(31 \mathrm{ft})$ bgs. Borehole B2 was located

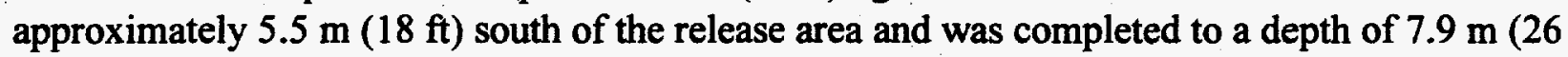

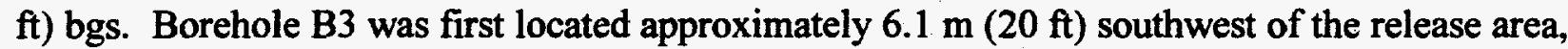
however, hydrocarbon odors were noted and confirmed to be present in grab samples screened using PetroFLAG ${ }^{\mathrm{TM}}$. The borehole was terminated and abandoned at a depth of $4.6 \mathrm{~m}(15 \mathrm{ft})$

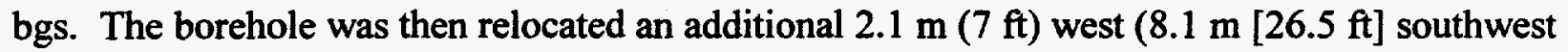
of the release area) and was completed to a depth of $7.9 \mathrm{~m}(26 \mathrm{ft}) \mathrm{bgs}$. 


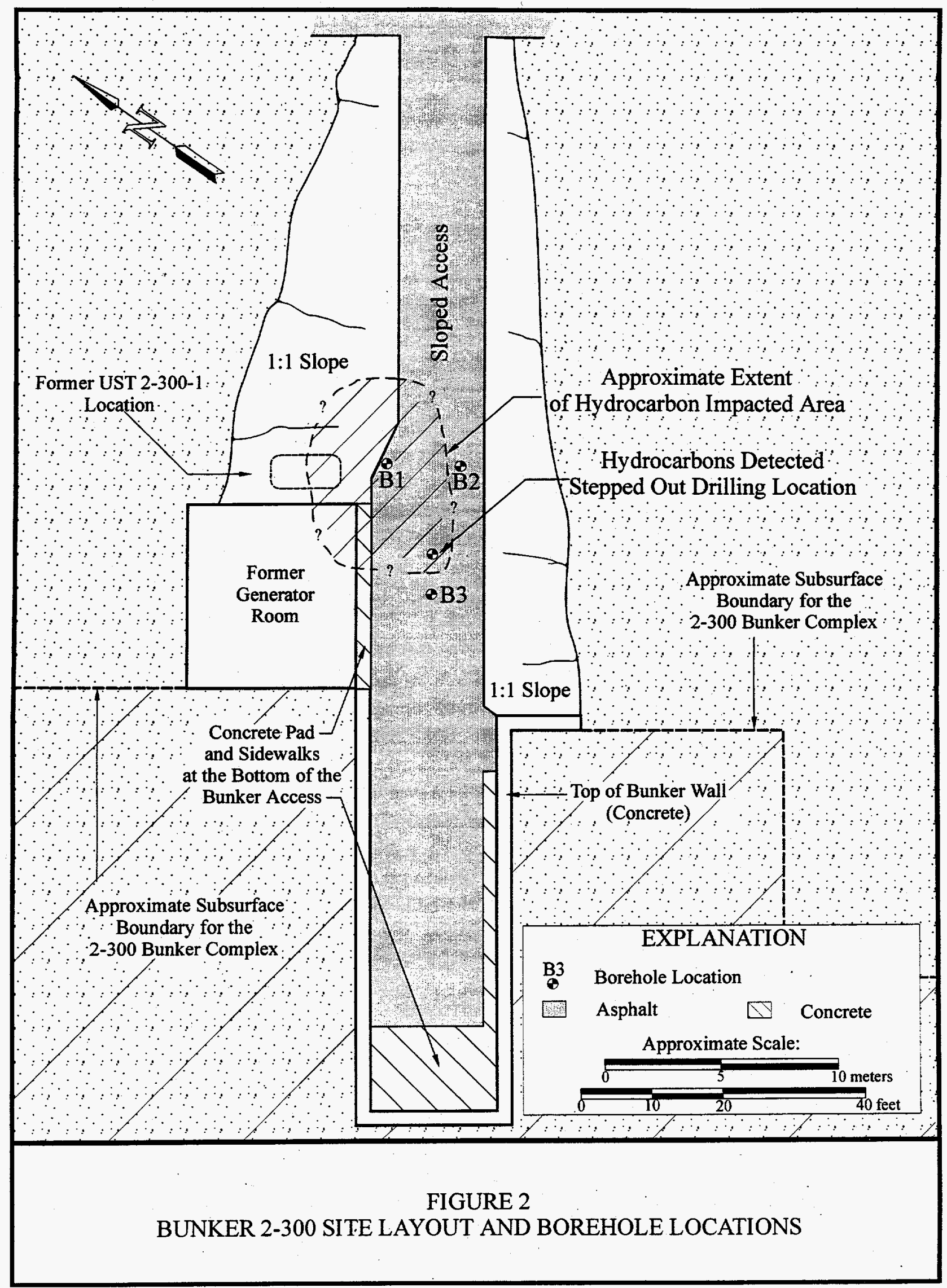


Upon completion of each borehole, clean-graded sand was slowly placed into the borehole using the augers as a tremmie pipe to prevent bridging. The upper $1.5 \mathrm{~m}(5 \mathrm{ft})$ was then filled with approximately $0.3 \mathrm{~m}$ to $0.6 \mathrm{~m}$ ( $1 \mathrm{ft}$ to $2 \mathrm{ft})$ of $1.0-\mathrm{cm}(3 / 8-\mathrm{in})$ bentonite pellets, hydrated, and sealed with a concrete plug. Field observations and analytical results are discussed and summarized in Section 4.0, Closure Results.

\subsubsection{Description and Background: Release Site 9-300-1}

UST 9-300-1 was located on the east side of the Area 9 Bunker 300. Area 9 is an historic aboveground nuclear testing area and many of the areas surrounding the 9-300 Bunker are posted for radiation contamination. The former tank had an approximate capacity of $1,900 \mathrm{~L}$ (500 gal) and supplied diesel fuel for generators. The tank was full at the time of the initial field identification. The tank was removed on May 2, 1996. A soil sample collected from below the south tank bottom had a TPH concentration of $3,300 \mathrm{mg} / \mathrm{kg}$. It is believed that the release was a result of historical periodic product line leakage based upon the tank being full at the time of field identification, no soil staining observed above or directly below the tank at the time of closure, and no apparent holes or rust observed on the tank. Closure of the hydrocarbon release (NDEM No. 960701-849, CAS No. 09-02-01) is addressed in this report.

\subsubsection{Excavation Activities: Release Site 9-300-1}

The former tank area was excavated using a backhoe on November 19, 1997, as outlined in the SAFER Work Plan (US DOE, 1997). Excavation of the impacted soil associated with the release from 9-300-1 was complicated by a concrete footing that extended out from the 9-300 Bunker. The impacted soil appeared to be localized in an area where the copper product lines fed into the concrete bunker footing. The excavation was extended to a depth of approximately $1.7 \mathrm{~m}(5.5 \mathrm{ft}$ ) below the copper piping (or approximately $3 \mathrm{~m}[10 \mathrm{ft}]$ below the former tank bottom). A soil sample was collected from the backhoe bucket using a stainless steel scoop and analyzed for TPH as diesel. Approximately 11.5 cubic meters $\left(\mathrm{m}^{3}\right)\left(15\right.$ cubic yards $\left.\left[\mathrm{yd}^{3}\right]\right)$ of hydrocarbon-impacted soils were removed from the site. Soils were stockpiled on and covered with plastic at the site pending disposal. A site map is provided as Figure 3. Field observation and analytical results are summarized in Section 4.0, Closure Results.

\subsection{DEVIATIONS FROM THE SAFER WORK PLAN}

Deviations from the SAFER Work Plan were minimal. At the 2-300-1 site the scheduled up gradient borehole (2-300-B2) could not be installed at the designated location due to terrain limitations. Instead this borehole was used to delineate the southern extent of the release. Two additional unscheduled boreholes were installed southwest of borehole 2-300-B1. These two 
Date: April 22, 1998

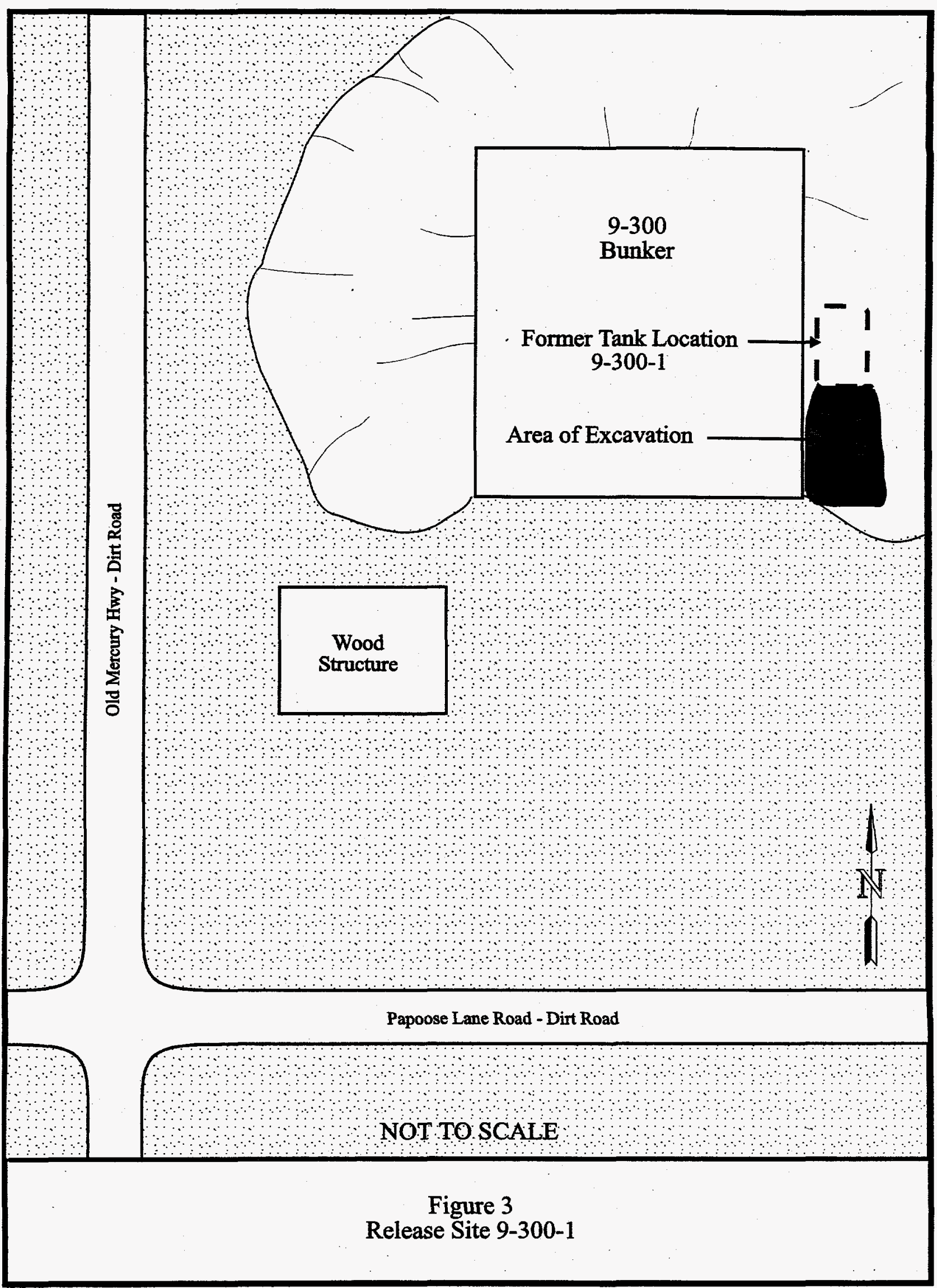


boreholes were used to identify the southwestern extent of impacted soil. In addition, the initial sample depth was modified in some instances to correlate with the depth at which hydrocarbons were encountered in other boreholes.

Soil samples were not delivered to the Bechtel Nevada Analytical Services Section as stated in the SAFER Work Plan. In order to expedite analysis, the soil samples were retained by the project geologist and delivered to NEL.

Borehole locations and the clean closure excavation were not surveyed using the Global Positioning System. Since each borehole and the clean closure excavation is adjacent to Bunker structures which are not anticipated to be removed in the near future, it was determined that an accurate site plan could be created from field measurements.

Impacted soils from the 2-300 drilling site were placed into 208-L (55-gal) metal drums instead of being placed into a soil pile. Drums were more efficient for handling and transporting the soil out of the work area due to the limited access available at the drill site.

\subsection{CORRECTIVE ACTION SCHEDULE AS COMPLETED}

Drilling was completed without significant delays due to inclement weather, equipment breakdown, or laboratory analysis. Drilling at the 2-300 release site was started on February 3, 1998, and completed on February 9, 1998, and consisted of the completion of four boreholes (including one step out location). Soil disposal occurred on February 18, 1998.

Excavation activities at the 9-300 release site were completed on November 19, 1997. Soil disposal occurred on December 9, 1997. The project schedule for the completed field activities is provided in Figure 4.

\subsection{SITE PLAN}

Site plans have been prepared depicting the site locations (Figures 2 and 3). Since no modifications to subsurface utilities or facilities were made, engineering "as-builts" are not required. However, a copy of the site plans will be submitted to the files at the Archives and Records Center located in Mercury, Nevada. 


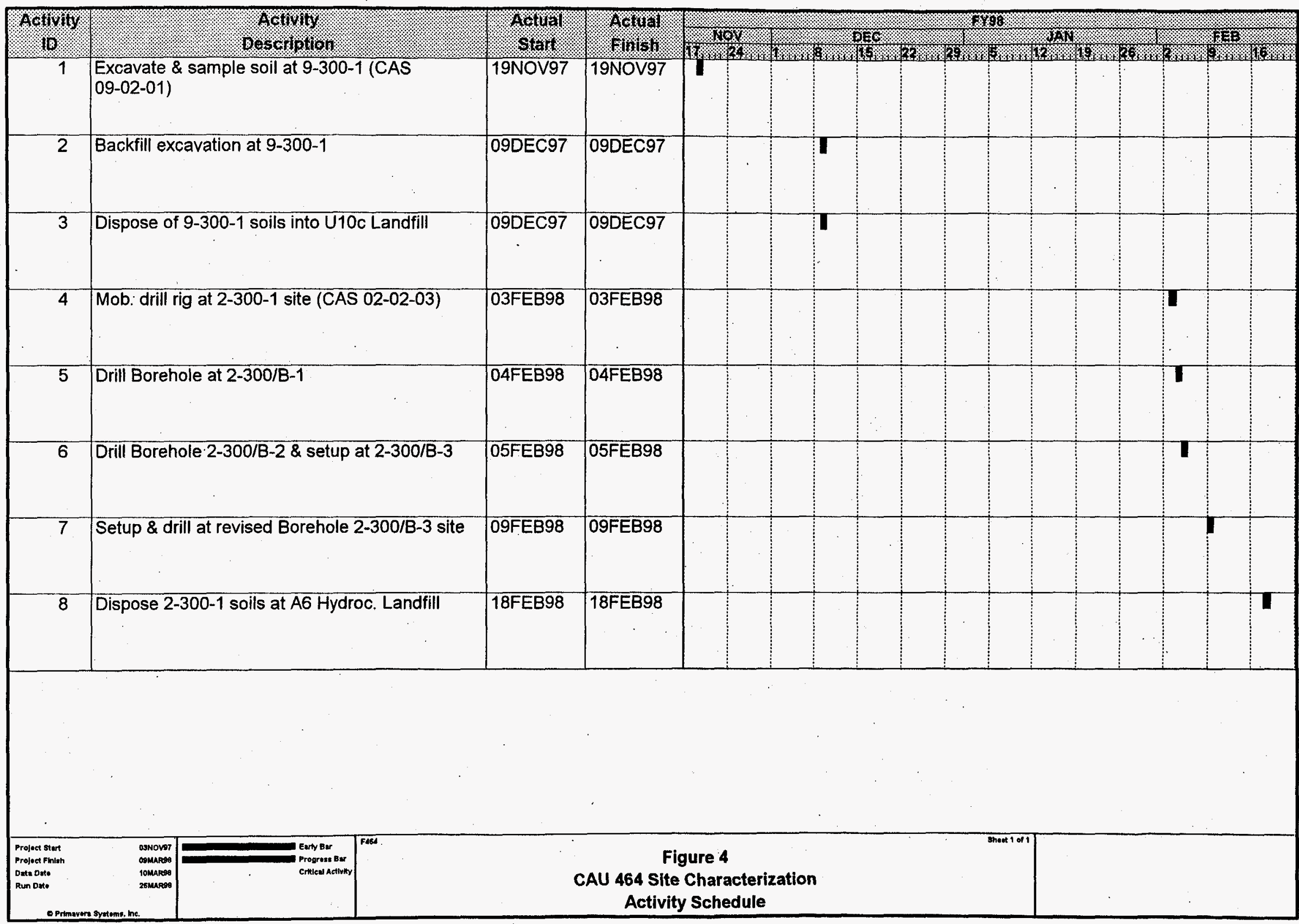




\subsection{WASTE DISPOSITION}

Waste generated from the drilling activities consisted of hydrocarbon-impacted soils and decontamination rinseate water. Soils generated from the 2-300 release site were managed by placing the drill cuttings into 208-L (55-gal) metal drums. Soil from the 9-300 release site was placed on and covered with plastic pending disposal. Decontamination rinseate water, generated from sampling and drilling equipment, was solidified using the soils from the sites, or by adding bentonite.

Each site was assigned a waste tracking number. The tracking number for the 2-300 site was applied to the outside of each drum along with the corresponding borehole identification and date generated. Soil from the 2-300 site was disposed of at the Area 6 Hydrocarbon Landfill on February 18, 1998. The tracking number for the 9-300 site was applied to the outside of the plastic soil pile cover. Soil from the 9-300 site was disposed of at the U10c Landfill on December 9, 1997.

Landfill acceptance of the soil and solidified rinseate was based on the analytical data collected during the tank closure and/or laboratory analysis of the additional verification and characterization samples. A radiological "green tag," bill of lading, and weight ticket accompanied each load to the respective landfills. Landfill disposal documentation is provided in Appendix B. 


\subsection{CLOSURE RESULTS}

\subsection{RELEASE SITE 2-300-1 (CAS 02-02-03)}

Three boreholes were drilled at this site in order to define the lateral and vertical extent of the petroleum hydrocarbon release. Figure 2 provides a plan view of the site indicating the borehole locations and estimated lateral extent of hydrocarbon impact.

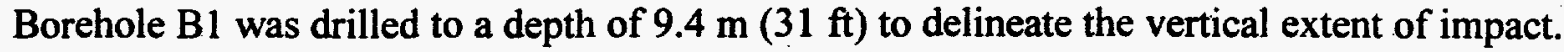

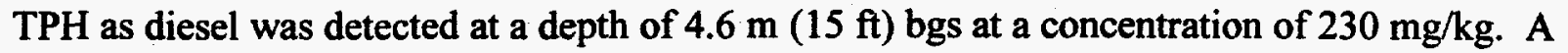

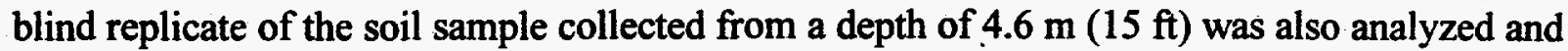
was reported to have a TPH concentration of $370 \mathrm{mg} / \mathrm{kg}$. Samples collected at depths of $6.1 \mathrm{~m}$ $(20 \mathrm{ft}), 7.6 \mathrm{~m}(25 \mathrm{ft})$, and $9.1 \mathrm{~m}(30 \mathrm{ft})$ did not contain TPH as diesel above the method detection limit (MDL) of $20 \mathrm{mg} / \mathrm{kg}$. The vertical extent of the diesel release was determined not to exceed $6.1 \mathrm{~m}(20 \mathrm{ft})$ bgs.

Borehole B2 was installed south of the hydrocarbon release area. Samples collected from depths of $3.0 \mathrm{~m}(10 \mathrm{ft}), 4.6 \mathrm{~m}(15 \mathrm{ft}), 6.1 \mathrm{~m}(20 \mathrm{ft})$, and $7.6 \mathrm{~m}(25 \mathrm{ft})$ bgs were below the MDL of $20 \mathrm{mg} / \mathrm{kg}$. The lateral extent of hydrocarbon impact to the south was defined by Borehole B2 and was determined not to exceed a distance of $5.5 \mathrm{~m}(18 \mathrm{ft})$ from the release area.

Borehole B3 was installed southwest of the release area. Since hydrocarbons were identified in the first location of Borehole B-3, the location was moved (Figure 2). Samples collected from depths of $3.0 \mathrm{~m}(10 \mathrm{ft}), 4.6 \mathrm{~m}(15 \mathrm{ft}), 6.1 \mathrm{~m}(20 \mathrm{ft})$, and $7.6 \mathrm{~m}(25 \mathrm{ft})$ bgs were below the MDL of $10 \mathrm{mg} / \mathrm{kg}$. The lateral extent of hydrocarbons to the southwest was defined by Borehole B3 and was determined not to exceed a distance of approximately $8.2 \mathrm{~m}(27 \mathrm{ft})$ from the release area.

Soils at the site consisted of clayey gravel to gravelly clay and silty sands. Drilling logs detailing the lithologic conditions, PetroFLAG ${ }^{\mathrm{TM}}$. results, and OVM readings, are provided in Appendix C. Sample analytical results and PetroFLAG ${ }^{\mathrm{TM}}$ screening results are provided in Table 2. Laboratory analytical results are provided in Appendix D.

Based on the site observations, the hydrocarbon concentrations detected, and the delineation of the vertical and lateral extent of subsurface hydrocarbons, an "A through $\mathrm{K}$ " evaluation to support an Administrative Closure of the site has been completed.

\subsubsection{A Through K Evaluation: UST Release Site 2-300-1}

The following is the NAC "A through $\mathrm{K}$ " evaluation which supports the request for an Administrative Closure of CAS 02-02-03 (NAC, 1996). 
TABLE 2 - DRILL SITE 2-300-1: SUMMARY OF SOIL ANALYTICAL RESULTS

\begin{tabular}{|c|c|c|c|c|c|}
\hline $\begin{array}{c}\text { BOREHOLE } \\
\text { ID }\end{array}$ & $\begin{array}{c}\text { SAMPLE } \\
\text { ID }\end{array}$ & $\begin{array}{c}\text { DATE } \\
\text { SAMPLED }\end{array}$ & $\begin{array}{l}\text { SAMPLE } \\
\text { DEPTH } \\
\text { meters } \\
\text { [feet] }\end{array}$ & $\begin{array}{c}\text { TPH' } \\
\text { DIESEL } \\
\text { (mg/kg) }\end{array}$ & $\begin{array}{l}\text { PETROFLAG }^{\text {ma }} \\
\text { RESULTS } \\
\text { (ppm) }\end{array}$ \\
\hline \multirow[t]{4}{*}{ Borehole 1* } & $\begin{array}{c}\text { 2-300/B1@15 } \\
\text { 2-300/B1@18 } \\
\text { (blind replicate) }\end{array}$ & Feb. 4, 1998 & $4.6[15]$ & $\begin{array}{c}230 \\
370 \text { replicate }\end{array}$ & 825 \\
\hline & 2-300/B1@20 & Feb. 4, 1998 & $6.1[20]$ & $<20$ & 0 \\
\hline & 2-300/B1@25 & Feb. 4, 1998 & $7.6[25]$ & $<20$ & 0 \\
\hline & 2-300/B1@30 & Feb. 4, 1998 & $9.1[30]$ & $<20$ & 7 \\
\hline \multirow[t]{4}{*}{ Borehole 2} & 2-300/B2@10 & Feb. 5, 1998 & $3.0[10]$ & $<20$ & 150 \\
\hline & 2-300/B2@15 & Feb. 5, 1998 & $4.6[15]$ & $<20$ & 26 \\
\hline & 2-300/B2@20 & Feb. 5, 1998 & $6.1[20]$ & $<20$ & 49 \\
\hline & 2-300/B2@25 & Feb. 5, 1998 & $7.6[25]$ & $<20$ & 13 \\
\hline \multirow[t]{4}{*}{ Borehole 3} & 2-300/B3@10 & Feb. 9, 1998 & $3.0[10]$ & $<10$ & 7 \\
\hline & 2-300/B3@15 & Feb. 9, 1998 & $4.6[15]$ & $<10$ & 4 \\
\hline & 2-300/B3@20 & Feb. 9, 1998 & $6.1[20]$ & $<10$ & 10 \\
\hline & 2-300/B3@25 & Feb. 9, 1998 & $7.6[25]$ & $<10$ & 0 \\
\hline
\end{tabular}

\section{Notes:}

TPH $^{1}$ - Total petroleum hydrocarbons analyzed using US EPA Method 8015 Modified, as diesel.

Borehole B1* - The PetroFLAG ${ }^{\mathrm{TM}}$ result at $3.0 \mathrm{~m}(10 \mathrm{ft})$ was $>2,000 \mathrm{ppm}$. All other results reported in table above.

$\mathbf{m g} / \mathbf{k g}$ - milligrams per kilogram

ppm - parts per million 
State regulatory requirements - The state regulatory requirement affecting the closure of CAS 02-02-03 is the requirement of the NAC 459.9973, Action by Division When Excessive Petroleum Is Present in Soil, referred to as "A through K."

Depth of groundwater (A) - Depth to groundwater at the site is estimated to be at $597 \mathrm{~m}$ $(1,960 \mathrm{ft})$ bgs. The estimated depth is based on the regional general potentiometric surface map provided in the DOE Environmental Impact Statement (US DOE, 1996c).

Distance to irrigation or drinking water wells (B) - The nearest water supply is located at inactive Well 2 , approximately 3.0 kilometers $(\mathrm{km})(1.9 \mathrm{miles}$ [mi]) from the site. The static water level in 1984 was measured at $736 \mathrm{~m}(2,416 \mathrm{ft})$ bgs (RSN, 1986).

Type of soil (C) - Soils identified during the drilling activities consisted of clayey gravel to gravelly clay and silty sand.

Annual precipitation (D) - Annual rainfall in the site vicinity over a three-year period (February, 1960 to August 1964) is tabulated in the report, Daily, Seasonal, and Annual Precipitation At The Nevada Test Site. Nevada (DRI, 1986). The data was collected from "Station 353" and had a recorded average annual precipitation of $10.9 \mathrm{~cm}$ (4.31 in) for the time period measured (DRI, 1986).

Type of regulated substance released (E) - The tank formally located at the site was used to store diesel fuel for generators used at the bunker. TPH as diesel were identified in soil samples collected below the south bottom of the tank at maximum concentrations of $9,600 \mathrm{mg} / \mathrm{kg}$.

Extent of contamination (F) - The extent of impacted soils was determined from the drilling activities conducted in February 1998. The vertical extent of impact does not extend below a

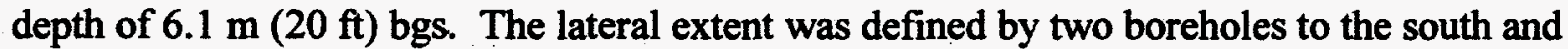
southwest of the release area. Based on analytical data and field observations, the lateral extent was defined by B2, located $5.5 \mathrm{~m}(18 \mathrm{ft})$ south of the release area and by B3 located $8.2 \mathrm{~m} \mathrm{(27}$ $\mathrm{ft})$ southwest of the release area. TPH was not detected above the MDL in the samples collected from Boreholes B2 $(<20 \mathrm{mg} / \mathrm{kg})$ and B3, $(<10 \mathrm{mg} / \mathrm{kg})$ each drilled to a depth of $7.9 \mathrm{~m}(26 \mathrm{ft})$ bgs.

Present and potential land use (G) - The site is located adjacent to the 2-300 Bunker Complex. The bunker and immediate surrounding area is currently used intermittently by testing laboratories. Since the bunker interior has been refurbished and is powered by electricity, it is anticipated that it will continue to be used in the future.

Preferred routes of migration/exposure pathways of concern $(\mathbf{H})$ - Since the release originated from a UST, surface migration is not a concern. The most likely route of migration, confirmed by the drilling data, would be vertically. However, it was determined that the vertical extent is minimal and due to the depth of groundwater, low amount of annual precipitation, large 
amount of evaporation, and the low TPH concentrations, it is unlikely that hydrocarbons would reach groundwater.

The site does not have an immediate inhalation or contact exposure pathway since the impacted soils are below the ground surface. In addition, the plume was defined to extend beneath the sloped embankment, asphalt covered bunker access, and the former generator room. Physical or dermal contact from the impacted soil will not occur unless excavation activity is completed within the tank area. Volatile organic compounds (VOCs) were not identified as an exposure concern during past excavation and drilling activities; therefore, inhalation of VOCs is not an expected pathway.

Location of structures or impediments (I) - The nearest structure to the release site is the bunker complex which borders the former tank area on the west (Figure 2). The other impediment is the narrow vehicle or equipment accessibility to the site.

Potential for hazard related to fire, vapor, or explosion (J) - The potential for fire, vapor ignition, or explosion at the site as a result of this release is extremely low. All of the impacted soils are below ground surface and are impacted with weathered diesel. Headspace measurements of impacted soil collected during site investigations were very low and support the conclusion that VOCs do not exist at the site at concentrations to support combustion.

Other factors specific to the site (K) - The following are additional factors specific to the site which should be considered in the evaluation for closure:

- The fuel tank was closed by removal in 1996 eliminating the original source of the subsurface release. In addition, during the tank removal and subsequent remedial and characterization activities, approximately $38\left(\mathrm{~m}^{3}\right)\left(50 \mathrm{yd}^{3}\right)$ of hydrocarbon-impacted soils were removed from the site. This reduced the volume of impacted soils as well as those soils with the highest hydrocarbon concentration.

- The site is located within the secured boundaries of the NTS. The area surrounding the site has craters from former underground nuclear testing activities in Area 2. The likelihood that the site will be used for future private use is very low.

- No other constituents of concern were identified at this release site and the concentrations of the petroleum hydrocarbons (diesel) detected decreased with depth and were not found to be a depths greater than $6.1 \mathrm{~m}(20 \mathrm{ft})$ bgs. 


\subsection{RELEASE SITE 9-300-1 (CAS 09-02-01)}

Soils at the site consisted of medium brown silty sand with minor gravels. Minor soil staining and odors were noted in a location where a portion of the former product lines entered the bunker footing. However, the remaining portion of the lines were removed and no staining or odors were noted below the product lines.

One soil sample was collected from the south bottom of the remedial excavation. TPH as diesel was not detected $(<10 \mathrm{mg} / \mathrm{kg})$ in the soil sample collected. In addition, the PetroFLAG ${ }^{\mathrm{TM}}$ and OVM screening results were each $0.0 \mathrm{ppm}$. Laboratory analytical results are provided in Appendix D. 


\subsection{CONCLUSIONS}

Site characterization and remediation was completed at two UST release sites identified as CAU 464. Characterization was completed using drilling equipment to delineate the extent of hydrocarbons at release site 2-300-1 (CAS 02-02-03). Clean closure was completed using a backhoe at release site 9-300-1 (CAS 09-02-01).

At the 2-300 release site, the vertical extent of impacted soil was determined not to extend below a depth of $6.1 \mathrm{~m}(20 \mathrm{ft})$ bgs. The lateral extent was defined by two boreholes and was determined not to extend beyond a maximum distance of $8.2 \mathrm{~m}(27 \mathrm{ft})$ from the release site. Based on the site observations, the low hydrocarbon concentrations detected, and the delineation of the vertical and lateral extent of subsurface hydrocarbons, an "A through $K$ " evaluation supporting an Administrative Closure of the site was completed. In addition, by completing the tank closure and excavating approximately $38\left(\mathrm{~m}^{3}\right)\left(50 \mathrm{yd}^{3}\right)$ of impacted soil from the site, the source and contributing components to the identified release have been removed.

Clean closure was completed at release site 9-300-1 by excavating an additional $11.5 \mathrm{~m}^{3}\left(15 \mathrm{yd}^{3}\right)$ of impacted soils. TPH as diesel was not detected $(<10 \mathrm{mg} / \mathrm{kg})$ in the soil sample collected

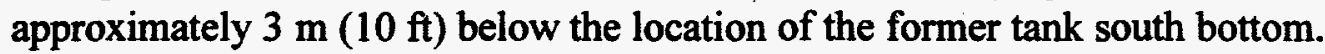

Based upon site observations and the soil sample analytical results, it is requested that a Notice of Completion be provided by the NDEP for each of the release CASs. Upon approval of the closure of the release CASs, CAU 464 will be promoted from Appendix III to Appendix IV of the FFACO "Closed Corrective Action Units." 


\subsection{REFERENCES}

BN, 1997a, Site Specific Health and Safety Plan for SAFER Closure of Historical UST Release Sites - Areas 2.9 12, 23, and 25, prepared by Bechtel Nevada Environmental Remediation Projects.

BN, 1997b, Field Management Plan: CAU 452, 454, 456, and 464 Closure of Historical UST Release Sites, Nevada Test Site, prepared by Bechtel Nevada Environmental Remediation Projects.

BN, 1997c, Closure of Historical UST Release Sites, Construction Work Plan, prepared by Bechtel Nevada Construction.

DRI, 1986, Daily, Seasonal, and Annual precipitation at the Nevada Test Site. Nevada, Desert Research Institute Water Resources Center, Las Vegas, Nevada, September 1986.

FFACO, 1996, Federal Facility Agreement and Consent Order agreed to by the State of Nevada, The US Department of Energy, and the US Department of Defense.

NAC 459.9973, 1996, Nevada Administrative Code, Chapter 459, Presence of excessive petroleum in soil: Evaluation: assessment of risk: corrective action. Carson City, Nevada: Nevada Division of Environmental Protection.

RSN, 1986, Nevada Site Development Plan, Part 1, Raytheon Services, Nevada.

US DOE, 1994, Nevada Environmental Restoration Project, Project Management Plan, Rev.0, Las Vegas, Nevada.

US DOE, 1996a, Nevada Environmental Restoration Project. Health and Safety Plan, Rev.2, Las Vegas, Nevada.

US DOE, 1996b, Nevada Environmental Restoration Project. Industrial Sites. Quality Assurance Project Plan. Nevada Test Site, Nevada, Rev.1, DOE/NV-372, Las Vegas, Nevada.

US DOE, 1996c, Environmental Impact Statement for the Nevada Test Site and Off-Site Locations in the State of Nevada. Volume 1, Chapters 1-9, United States Department of Energy, Nevada Operations Office, Las Vegas Nevada, August 1996.

US DOE, 1997, SAFER Work Plan for CAUs 452.454, 456, and 464 Closure of Historical UST Release Sites, Nevada Test Site August 1997, DOE/NV-11718-133, UC-702. Las Vegas, Nevada, Environmental Restoration Division. 


\section{APPENDIX A}

\section{UST CLOSURE INFORMATION}


Paul J. Liebendorfer, P.E., Chief

Bureau of Federal Facilities

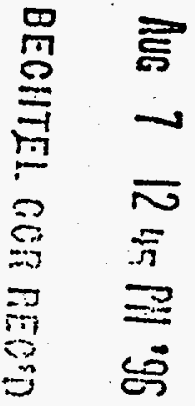

Division of Environmetal Protection

State of Nevada

333 W. Nye Lane

Carson City, NV 89710

\section{NOTIFICATION OF CLOSURE FOR NINE ENVIRONMENTAL RESTORATION (ER) PROGRAM ABANDONED UNDERGROUND STORAGE TANKS (USTS) CAU-418}

Please find enclosed the U.S. Environmental Protection Agency (EPA) Form 7530-1, Notification for Underground Storage Tanks, which identifies nine abandoned USTs that were permanently closed by removal. The USTs were closed under the DOE Nevada Operations Office (DOENNV) Environmental Restoration Abandoned UST Closure Program (FY 1996). The Intent to Close Notification form for the tanks was submitted by DOE/NV to the NDEP for eight of the nine tanks on November 21, 1995, and the ninth tank on February 12, 1996. The permanently closed tanks are as follows:
2-300-1 (Area 2, Bunker 300)
5-617-1 (Area 5, Bunker 617)
12-B-2 (Area 12, B Tunnel)
12-B-3 (Area 12, B Tunnel)
25-3124-1 (Area 25, TTF)
9-300-1 (Area 9, Bunker 300)
23-155-1 (Area 23, Bldg. 155)
25-3127-1 (Area 25, CP Cafeteria)
26-2201-2 (Area 26, Disassembly Bldg.)

Copies of the laboratory analytical results of soil samples collected below the bottom ends of the tanks are enclosed and summarized in Table 1. Laboratory analyses requested for the soil samples were based on the composition of product inside each tank or process knowledge of the tanks prior use.

The NDEP has been notified that the 2-300-1, 9-300-1, and 12-B-3 tank sites have total petroleum hydrocarbon concentrations in soil which exceed the 100 milligram per kilogram Action Level. The Nevada Division of Emergency Management Case Numbers assigned to the 2-300-1, 9-300-1, and 12-B-3 sites are 960603-771, 960701-849, and 960722-02, respectively. Additional soil sampling at each of the sites is required to further evaluate site conditions.

$$
\text { 95. W. }
$$




\section{1}

Paul J. Liebendorfer

$-2-$

All $2 g$ 1996

If you have any questions, please contact Sabine T. Curtis at 295-0542.

Original Sigñed $\mathrm{e}$

ERD:STC

David S. Shafer, Acting Director

Environmental Restoration Division

Enclosure: .

As stated feled in ENS1O

cc w/encl:

V. D. Mireau, NDEP, Las Vegas, NV

G. J. Sieren, NDEP, Las Vegas, NV

bcc w/encl:

D. D. Madsen, BN, Mercury, NV

S. J. Nacht, BN, Mercury, NV

S. T. Curtis, ERD, DOE/NV,

Las Vegas, NV

bcc w/o encl:

D. S. Shafer, ERD, DOE/NV, Las Vegas, NV

P. L. Hall, ERD, DOE/NV, Las Vegas, NV 


\section{ENVIRONMENTAL RESTORATION PROGRAM ABANDONED UNDERGROUND STORAGE TANKS (FY96) NOTIFICATION OF CLOSURE}


Sheet 1 of 8

Attention: UST Coordinator

Division of Environmental Protection

Dept. of Conservation and Natural Resources

EDA lom 75301 iRent

\begin{tabular}{|c|c|}
\hline Notification for Underground Storage Tanks & STATE USE ONLY \\
\hline Capital Complex - 201 S. Fall Street, Carson City, Nevada 89710 & \multirow{2}{*}{$\begin{array}{l}\text { ID NUMBER } \\
\text { DATE RECEIVED }\end{array}$} \\
\hline TYPE OF NOTIFICATION & \\
\hline $\begin{array}{l}Y \text { B. AMENDED } \\
\end{array}$ & \multirow{4}{*}{$\begin{array}{l}\text { A. Date Entered Into Computer } \\
\text { B. Data Entry Clerk Initials } \\
\text { C. Owner Was Contacted to } \\
\text { Clarify Responses. Comments }\end{array}$} \\
\hline 146 No. of tanks at tacility No. of continuation sheets attached & \\
\hline INSTRUCTIONS & \\
\hline $\begin{array}{l}\text { Please type or print in ink all items except "signature" in section V. This form } \\
\text { must be completed for each location containing underground storage tanks. If } \\
\text { more than five (5) tanks are owned at this location, photocopy the following } \\
\text { sheets, and staple continuation sheets to the form. }\end{array}$ & \\
\hline
\end{tabular}

\section{GENERAL INFORMATION}

Notification is required by Federal law for all underground tanks that have been used to store regulated substances since January 1, 1974, that are in the ground as of May 8, 1986, or that are brought into use after May 8 , 1986. The information requested is required by Section 9002 of the Resource Conservation and Recovery Act, (RCRA), as amended.

The primary purpose of this notification program is to locate and evaluate underground tanks that store or have stored petroleum or hazardous substances. It is expected that the information you provide will be based on reasonably available records, or in the absence of such records, your knowledge, belief, or recollection.

Who Must Notify? Section 9002 of RCRA, as amended, requires that, unless exempted, owners of underground tanks that store regulated substances must notify designated State or local agencies of the existence of their tanks. Owner means-

a) in the case of an underground storage tank in use on November 8, 1984, or brought into use after that date, any person who owns an underground storage tank used for the storage, use, or dispensing of regulated substances, and

b) in the case of any underground storage tank in use before November 8 , 1984 , but no longer is in use on that date, any person who owned such tank immediately before the discontinuation of its use.

c) if the State agency so requires, any facility that has undergone any changes to facility information or tank system status (only amended tank information needs to be included).

What Tanks Are Included? Underground storage tank is defined as any one or combination of tanks that (1) is used to contain an accumulation of "regulated substances, " and (2) whose volume (including connected underground piping) is $10 \%$ or more beneath the ground. Some examples are underground tanks storing: 1. Gasoline, used oil, ot diesel fuel, and 2. industrial solvents, pesticides. herbicides or fumigants.

What Tanks Are Excluded? Tanks removed from the ground are not subject to notification. Other tanks excluded from notification are:

1. farm or residential tanks of 1,100 galions or less capacity used for storing motor fuel for noncommercial purposes:

2. tanks used for storing heating oil for consumptive use on the premises where stored:
3. septic tanks

4. pipeline facilities (including gathering lines) regulated under the Natural Pipeline Safety Act of 1968, or the Hazardous Liquid Pipeline Safety Act of 197 which is an intrastate pipeline facility regulated under State laws:

5. surface impoundments, pits, ponds, or lagoons;

6. storm water or waste water collection systems;

7. flow through process tanks:

8. liquid traps or associated gathering lines directly related to oil or gas production and gathering operations:

9. storage tanks situated in an underground area (such as a basement, cella mineworking, drif. shaft, or tunnel) if the storage tank is situate cpon or above t surface of the floor.

What Substances Are Covered? The notification requirements apply to ur ground storage tanks that contain regulated substances. This includes any substance defined as hazardous in section 101 (14) of the Comprehensive Environmental Response, Compensation and Liability Act of 1900 (CERCLA), the exception of those substances regulated as hazardous waste under Subtitle RCRA. It also includes petroleum, e.g., crude oil or any fraction thereof which liquid at standard conditions of temperature and pressure $(60$ degrees Fahrent and 14.7 pounds per square inch absolute).

Where to Notify? Send completed forms to:

When to Notify? 1. Owners of underground storage tanks in use or that ha been taken out of operation after January 1, 1974, but still in the ground, must by May $8,1986.2$. Owners who bring underground storage tanks into use afte 8,1986 , must notify within 30 days of bringing the tanks into use. 3 . If the Sta requires notification of any amendments to facility send information to State ag immediately.

Penalties: Any owner who knowingly fails to notify or submits false information shall be subject to a civil penalty not to exceed $\$ 10,000$ for e tank for which notification is not given or for which false information is submitted.

\section{OWNERSHIP OF TANK(S)}

\section{II: LOCATION OF TANK(S)}

If requred by State. give he geograptuc beaton of tanks by degrees..minutes. and seconds Examples Lat, 42,36, $12 \mathrm{~N}$ Long. 85,24. $17 \mathrm{~W}$

Latitude Not Applicabie

Longitude Not Applicable

(II same as Secton I. marx box nere $\square$ )

Faclity Name $\alpha$ Cornpany Site I0entier, as applicable

Nevada Test Site

Street Address (P.O. Box not acceptable)

Highway 95

\begin{tabular}{|c|c|c|}
\hline City & State & ZIP Code \\
\hline Mercury, & Nevada & 89093 \\
\hline County & \multicolumn{2}{|c|}{ Munadatiy } \\
\hline NYE & & \\
\hline
\end{tabular}

ZIP Code
$89193-8518$

counis

Phone Number (thave Avea Code)

(702) 295-1860
Nevada 


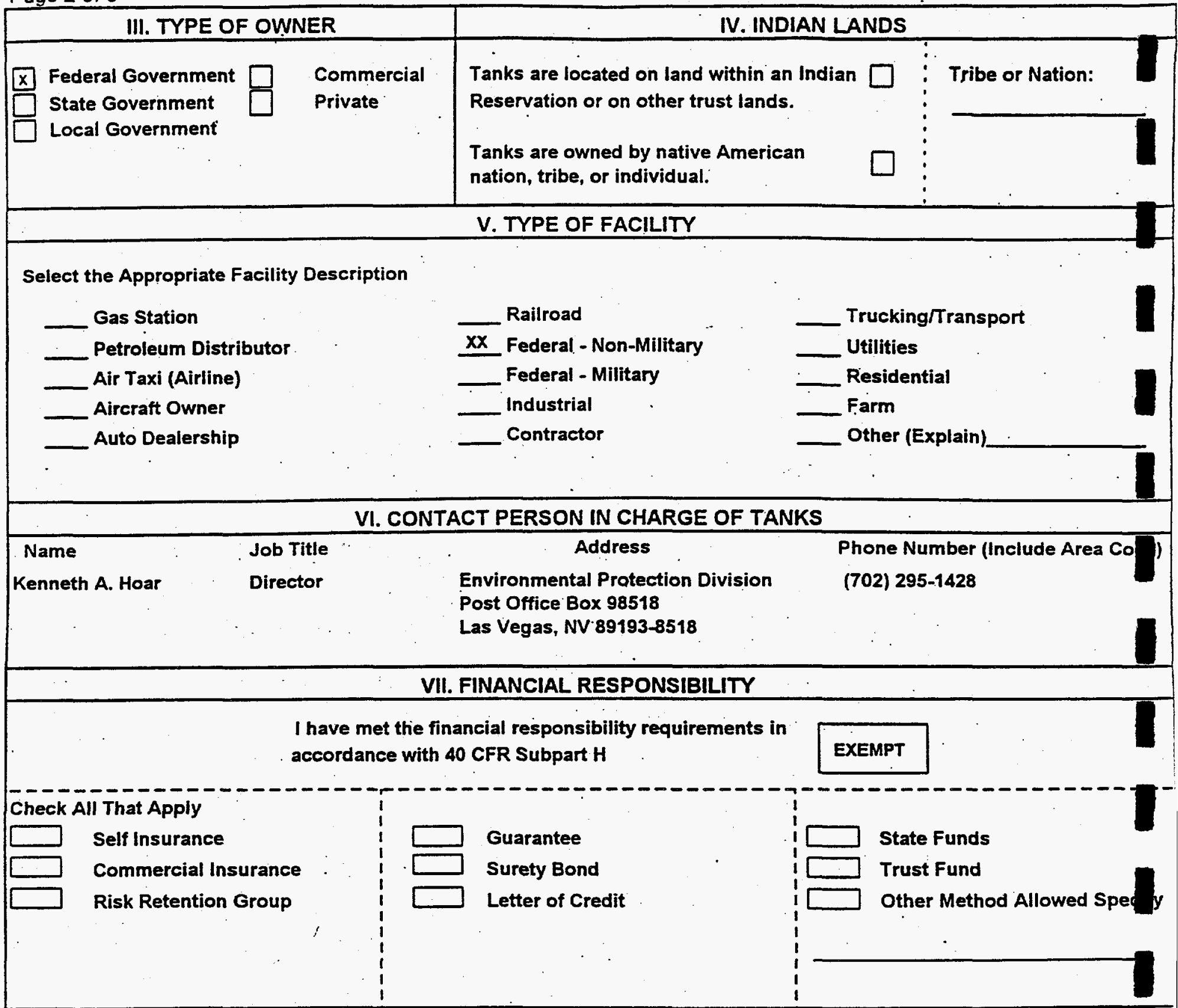

\section{CERTIFICATION (Read and sign after completing all sections)}

I certify under penalty of law that I have personally examined and am familiar with the information submitted in this and all attached documents, and that based on my inquiry of those individuals immediately responsible for obtaining the information, I believe that the submitted information is true, accurate, and complete.

Name and official title of owner or owner's authorized representative (Print)

Kenneth A. Hoar, Director

EPA estimates public reporting burden for this form to average 30 minutes per response including time for reviewing instructions, gathering and maintaining the data needed and completing and reviewing the form. Send comments regarding this burden estimate to Chief, Information Policy Branch PM-223, U. S. Environmental Protection Agency, 401 M Street, Washington D. C. 20460, marked "Attention Desk Officer for EPA." This form amends the previous notification form as printed in 40 CFR Part 280, Appendix $I$. Previous editions of this notification form may be used while supplies last. 
Page 3 of 8

IX. DESCRIPTION OF UNDERGROUND STORAGE TANKS (Complete for each tank at this location.)

Tank Identification Number

1. Status of Tank

(mark only one)

Currently in Use

Temporarily Out of Use

Remember to ftll out section $X$

Permanently Out of Use

(Remember lo fill out section $x$ )

Amendment of Information [Identified as Abandoned]

2. Date of Installation (mo./year)

3. Estimated Total Capacity (gallons)

4. Material of Construction

(Mark all that apply)

Asphalt Coated or Bare Steel

Cathodically Protected Stee

Epoxy Coated Steel

Composite (Steel with fiberglass)

Fiberglass Reinforced Plastic

Lined Interior

Double Walled

Polyethylene Tank Jacket

Concrete

Excavation Liner

Unknown

Other, Please Specify

Has Tank Been Repaired?

5. Piping (Material)

(Mark all that apply)
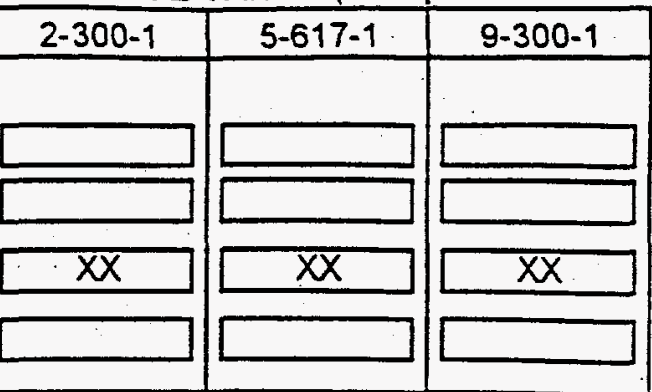

12-B-2

12-B-3
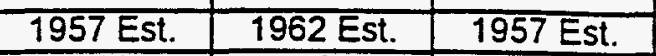

800
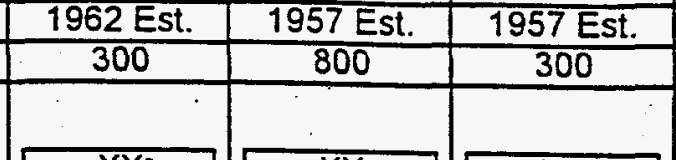

1957 Est.

XX
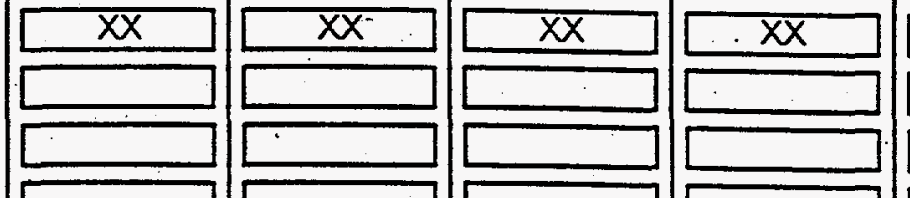

$\mathrm{XX}$

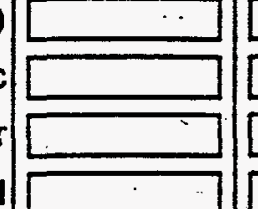

\section{$\square$}
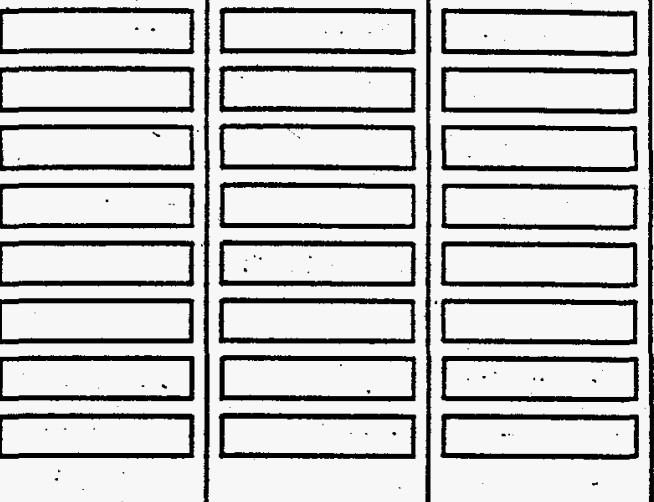

$$
\begin{aligned}
& \square \\
& \square \\
& \square \\
& \square
\end{aligned}
$$
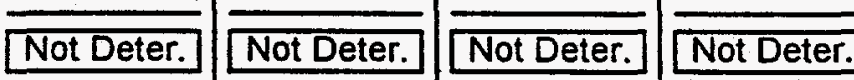

Not Deter.

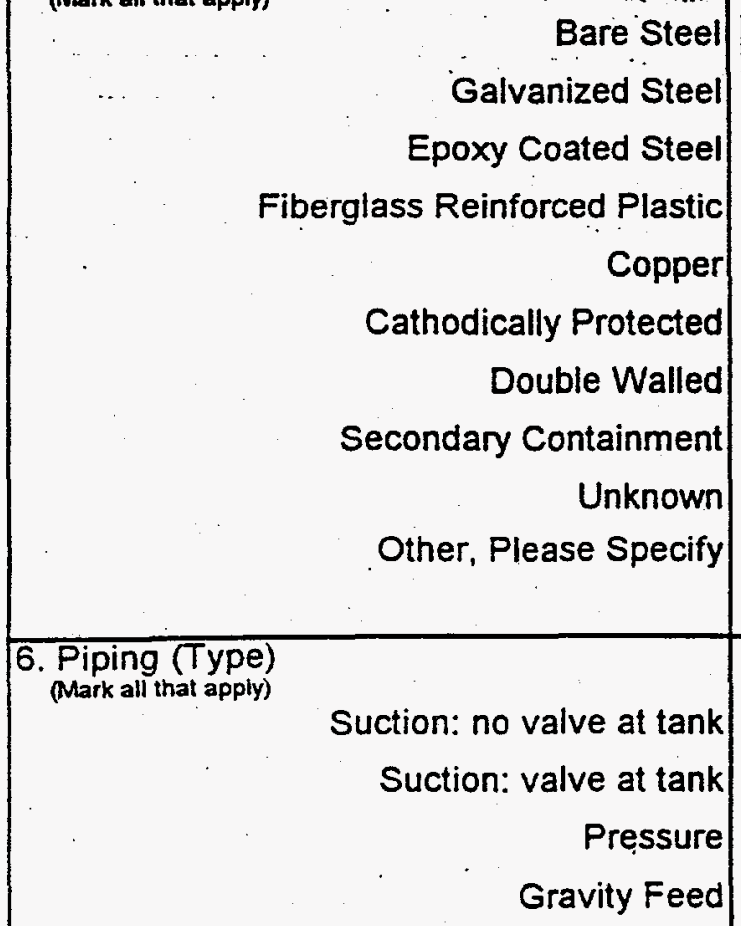

Has Piping Been Repaired?
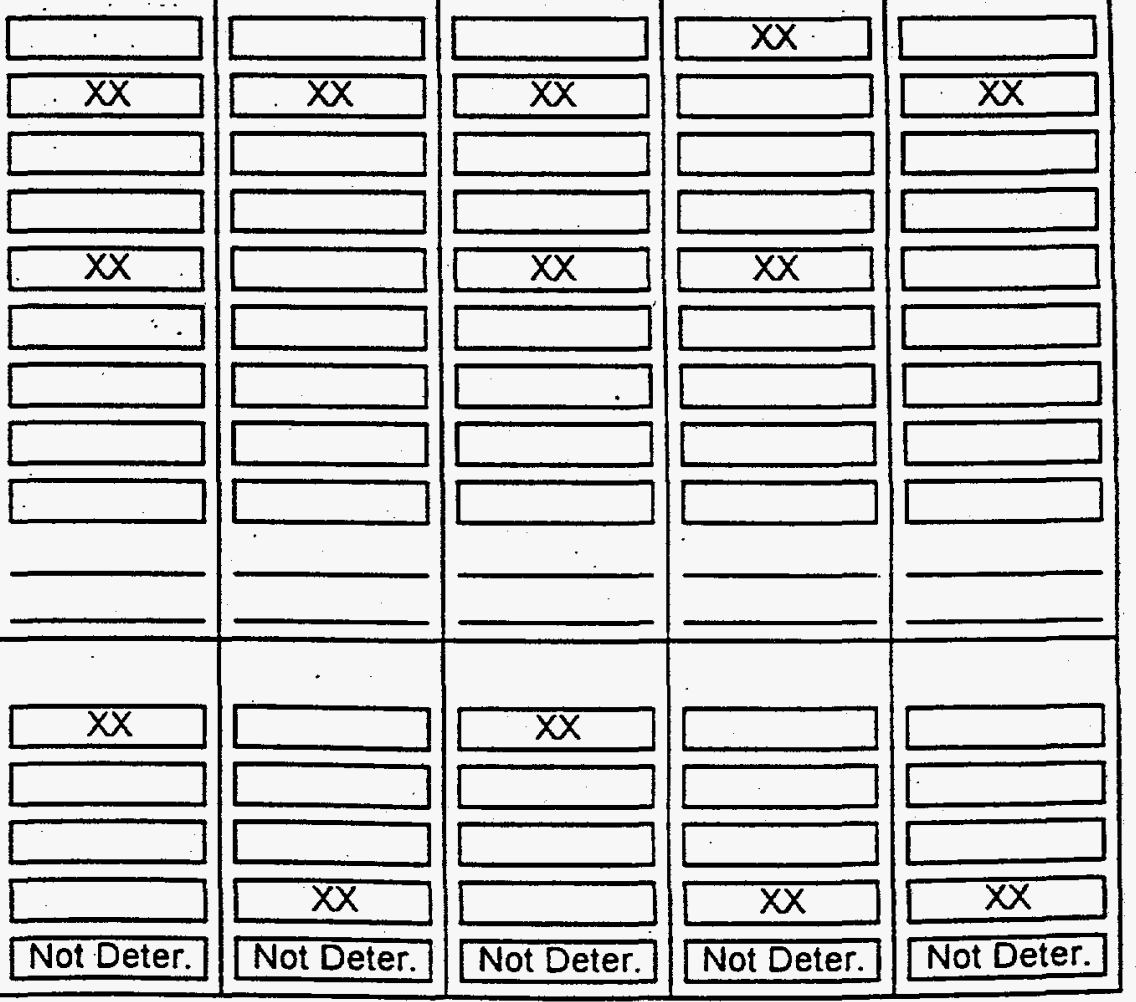
Page 4 of 8

Tank Identification Number

7. Substance Currently Used or Last Stored

in Greatest Quantity by volume

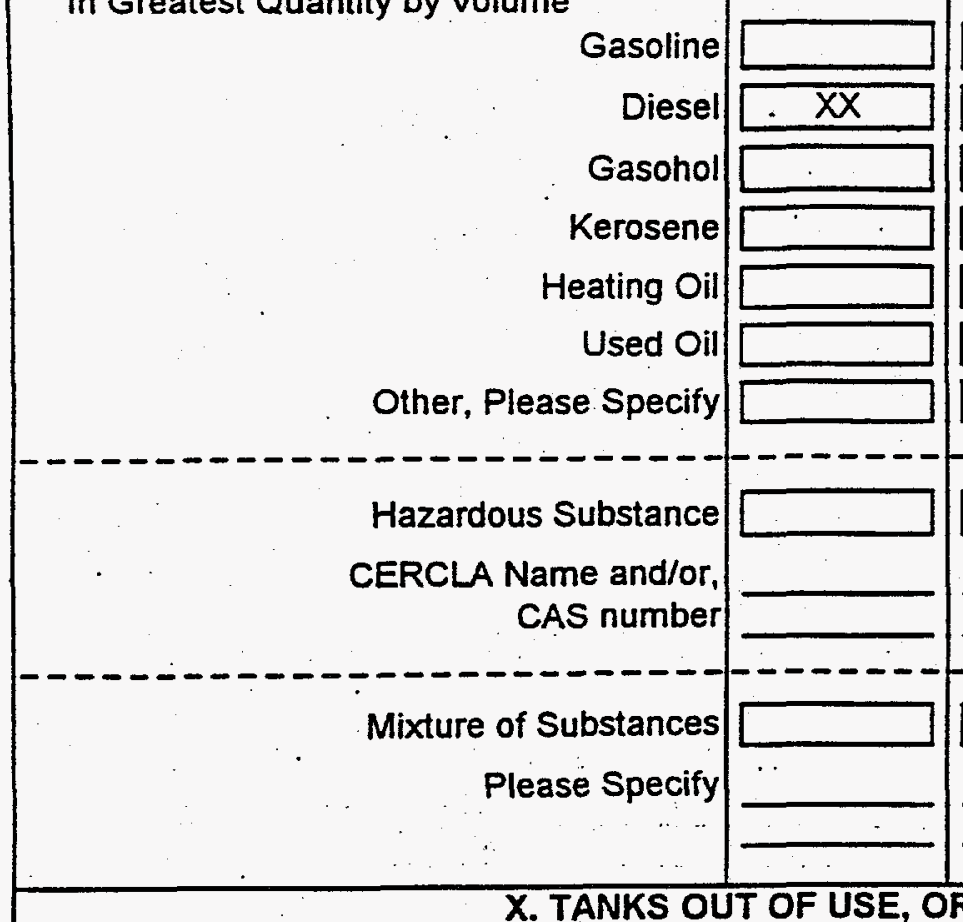

1. Closing of Tank

A. Estimated Date Last Used - - (mo./daylyear)

B. Estimated Date Tank Closed - (mo./day/year)

C. Tank Was Removed From Ground

D. Tank Was Closed In Ground

E. Tank Filled With Inert Material Describe

F. Change in Service

2. Site Assessment Completed Evidence Of A Leak Detected

T OF USE, OR CHANGE IN SERVICE

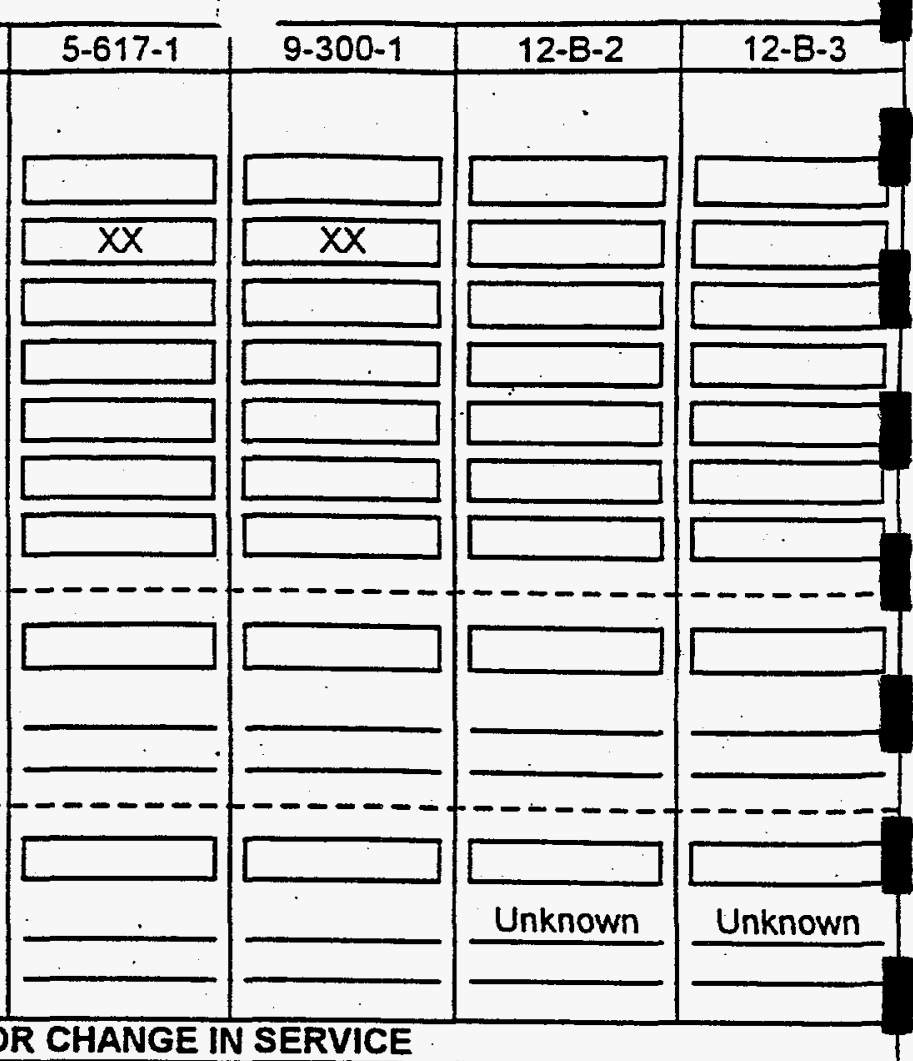

F. Change In Service

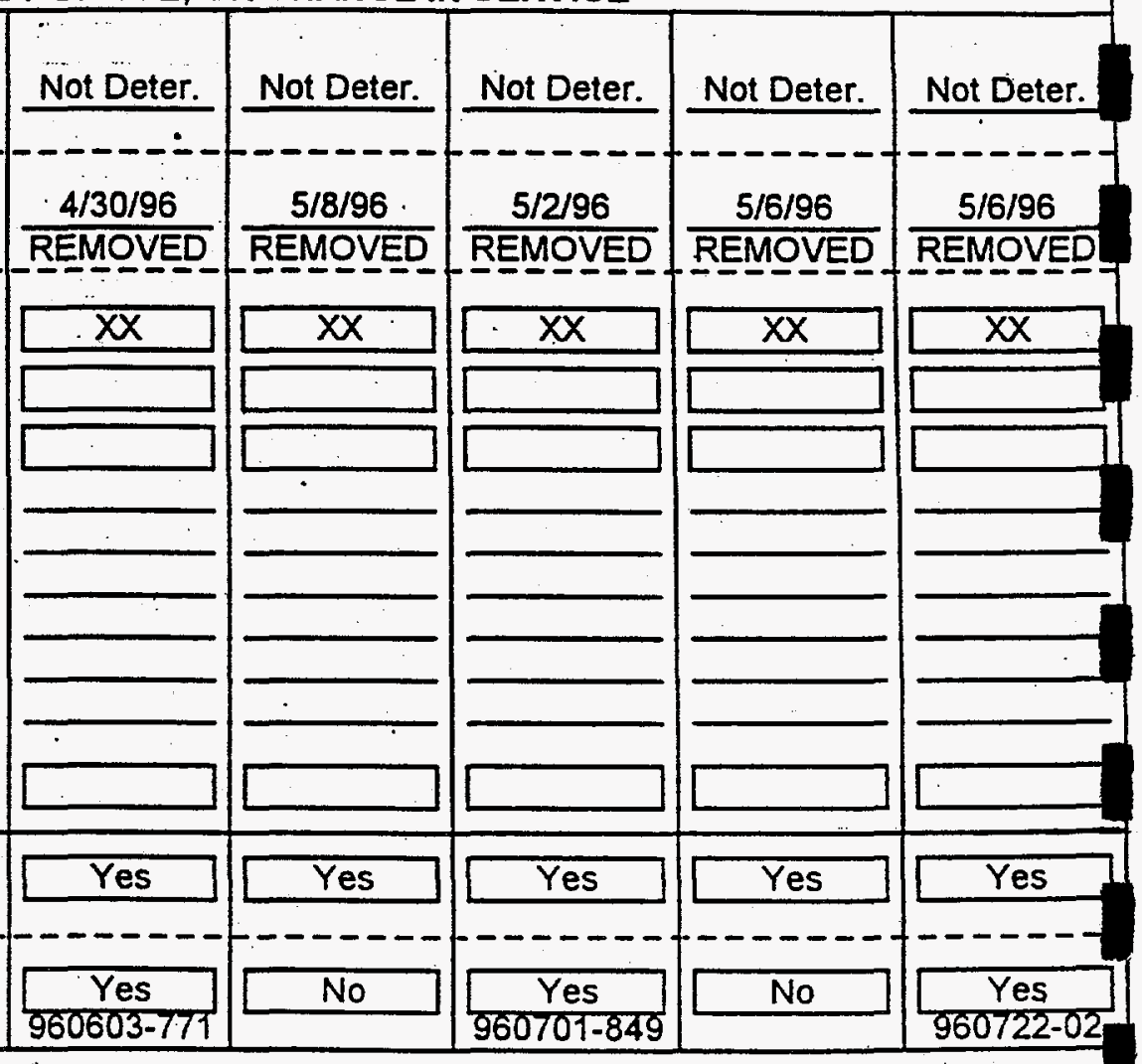


Page 5 of 8

\begin{tabular}{|c|c|c|c|c|c|c|c|c|c|c|}
\hline XI. CERTIFICATION OF COMPLIANCE & OMP & TE FOI & ALL & EW ANI & UPGR & ADED T & ANKS A & T THIS L & OCATI & \\
\hline Tank Identification Number & & $00-1$ & & $17-1$ & $9-3$ & $0-1$ & & $\mathrm{~B}-2$ & & $B-3$ \\
\hline 1. Installation & Not $A$ & plicable & Not $A$ & plicable & Not $A p$ & olicable & Not $A_{P}$ & plicable & $\operatorname{Not} A$ & plicable \\
\hline A. Installer certified by tank and & & & & & & & & & & \\
\hline piping manufactures & & & & & & & & & & \\
\hline B. Installer certified or licensed by & & & & & & & & & & \\
\hline the implementing agency & & & & & & & & & & \\
\hline C. Installer inspected by a & & & & & & & & & & \\
\hline registered engineer & & & & & & & & & & \\
\hline $\begin{array}{l}\text { D. Installer inspected and approved } \\
\text { by implementing agency }\end{array}$ & & & & & & & & & & \\
\hline $\begin{array}{l}\text { E. Manufacture's installation. } \\
\text { checkist have been completed }\end{array}$ & & & & & & & & & & \\
\hline F. Another method allowed by State & & & & & & & & & & \\
\hline agency. Please specify. & & & & & & & $\cdot$ & & & \\
\hline 2. Release Detection (Mark all that appiy) & TANK & PIPING & TANK & PIPING & TANK & PIPING & TANK & PIPING. & TANK & PIPING \\
\hline A. Manual tank guaging & & & & & & & & & & \\
\hline B. Tank tightness testing & & & & & & & & & & \\
\hline C. Inventory controls & & & & & & & & & & \\
\hline D. Automic tank guaging & & & & & & & & & & \\
\hline E. Vapor monitoring & & & & & I & & 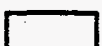 & & & \\
\hline F. Groundwater monitoring & & & & & & & & & & \\
\hline G. Interstitial monitoring double walled & & & & & & & & & & \\
\hline tank/piping & & & & & & & & & & \\
\hline H. Interstitial monitoring/secondary & & & & & L & & & & & \\
\hline containment & & & & & & & & & & \\
\hline I. Automic line leak detectors & & & & & & & & & & \\
\hline J. Line tightness testing & & & & & & & & & & \\
\hline K. Other method allowed by & & & & & & & & & & \\
\hline $\begin{array}{l}\text { Implementing Agency, Please } \\
\text { specify. }\end{array}$ & & & & & & & & & & \\
\hline & & & & & & & & & & \\
\hline 3. Spill and Overfill Protection & & & & & & & & & & \\
\hline A. Overfill device installed & & & & & L & & & & & \\
\hline B. Spill device installed & & & & & & & & & & \\
\hline
\end{tabular}

OATH: I certify the information concerning installation that is provided in section $X \mid$ is true to the best of my belief and knowledge. Installer: Not Applicable

Name


Page 6 of 8

IX. DESCRIPTION OF UNDERGROUND STORAGE TANKS (Complete for each tank at this location.)

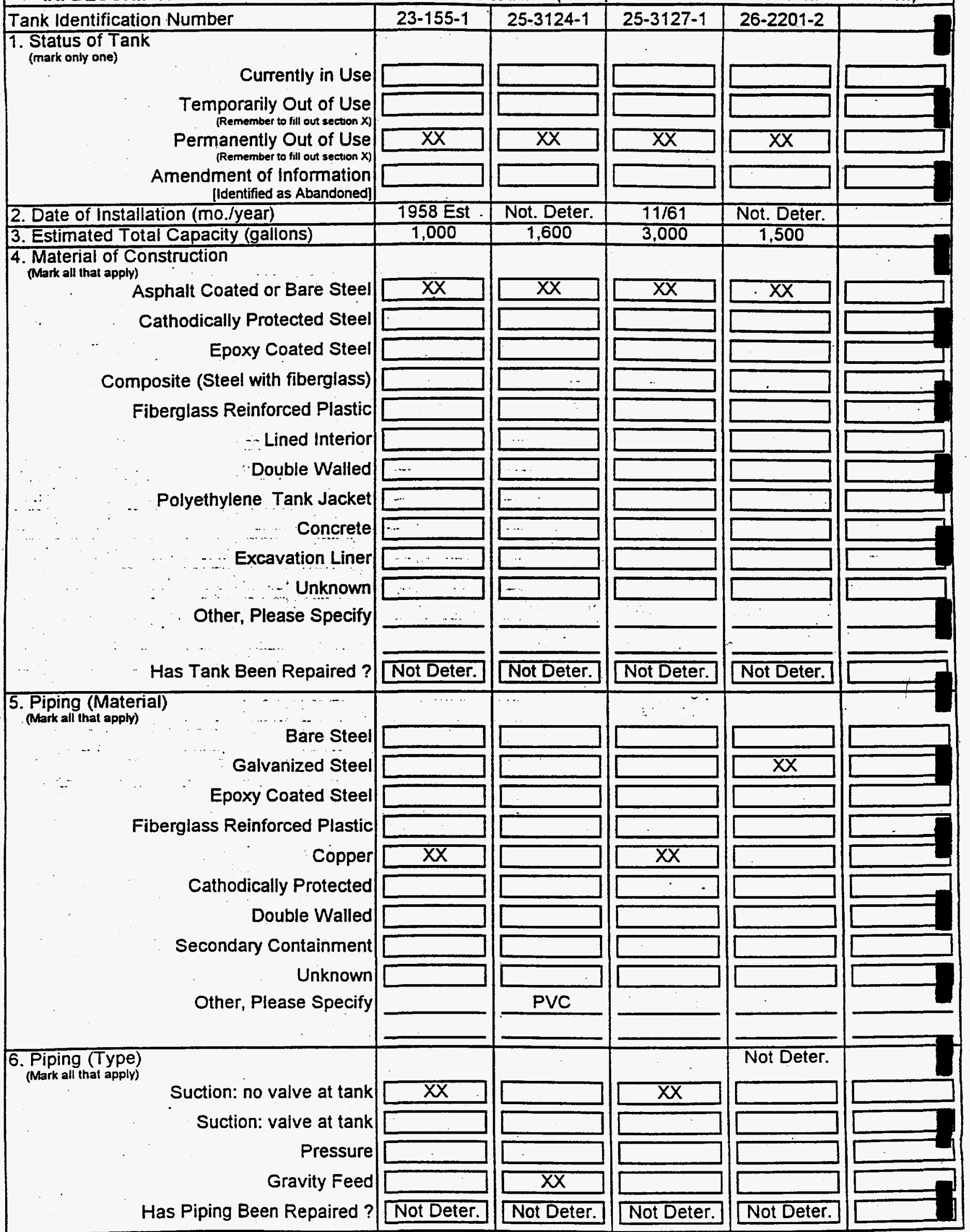


Page 8 of 8 .

XI. CERTIFICATION OF COMPLIANCE (COMPLETE FOR ALL NEW AND UPGRADED TANKS AT THIS LOCATION)

Tank Identification Number

1. Installation

A. Installer certified by tank and piping manufactures

B. Installer certified or licensed by the implementing agency

C. Installer inspected by a registered engineer

D. Installer inspected and approved by implementing agency

E. Manufacture's installation checklist have been completed

F. Another method allowed by State agency. Please specify.

2. Release Detection (Mark all that apply)

A. Manual tank guaging

B. Tank tightness testing

C. Inventory controls

D. Automic tank guaging

E. Vapor monitoring

F. Groundwater monitoring

G. Interstitial monitoring double walled tank/piping

H. Interstitial monitoring/secondary containment.

I. Automic line leak detectors

$\mathrm{J}$. Line tightness testing

$K$. Other method allowed by Implementing Agency, Please specify.

3. Spill and Overfill Protection
A. Overfill device installed
B. Spill device installed

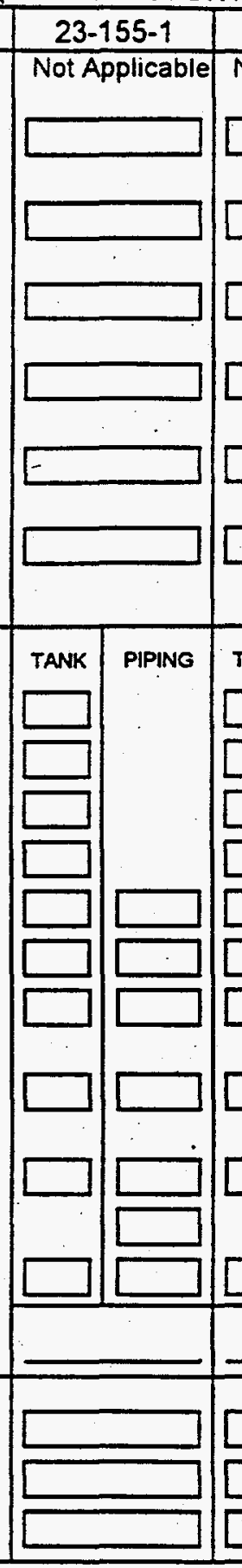

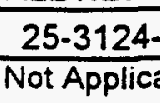
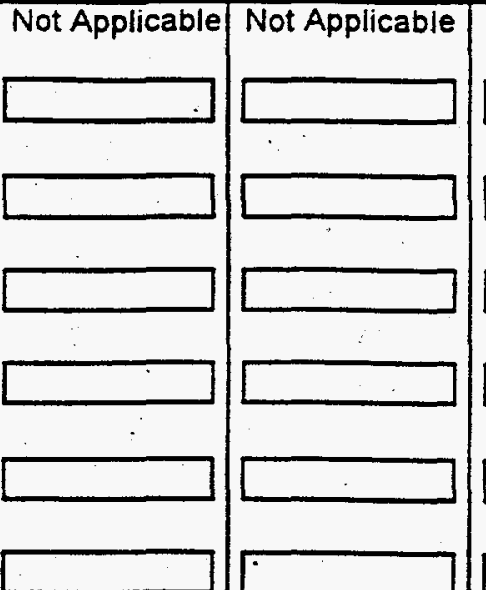

\begin{tabular}{|c|}
\hline $26-2201-2$ \\
\hline Not Applicable
\end{tabular}

Not Applicable
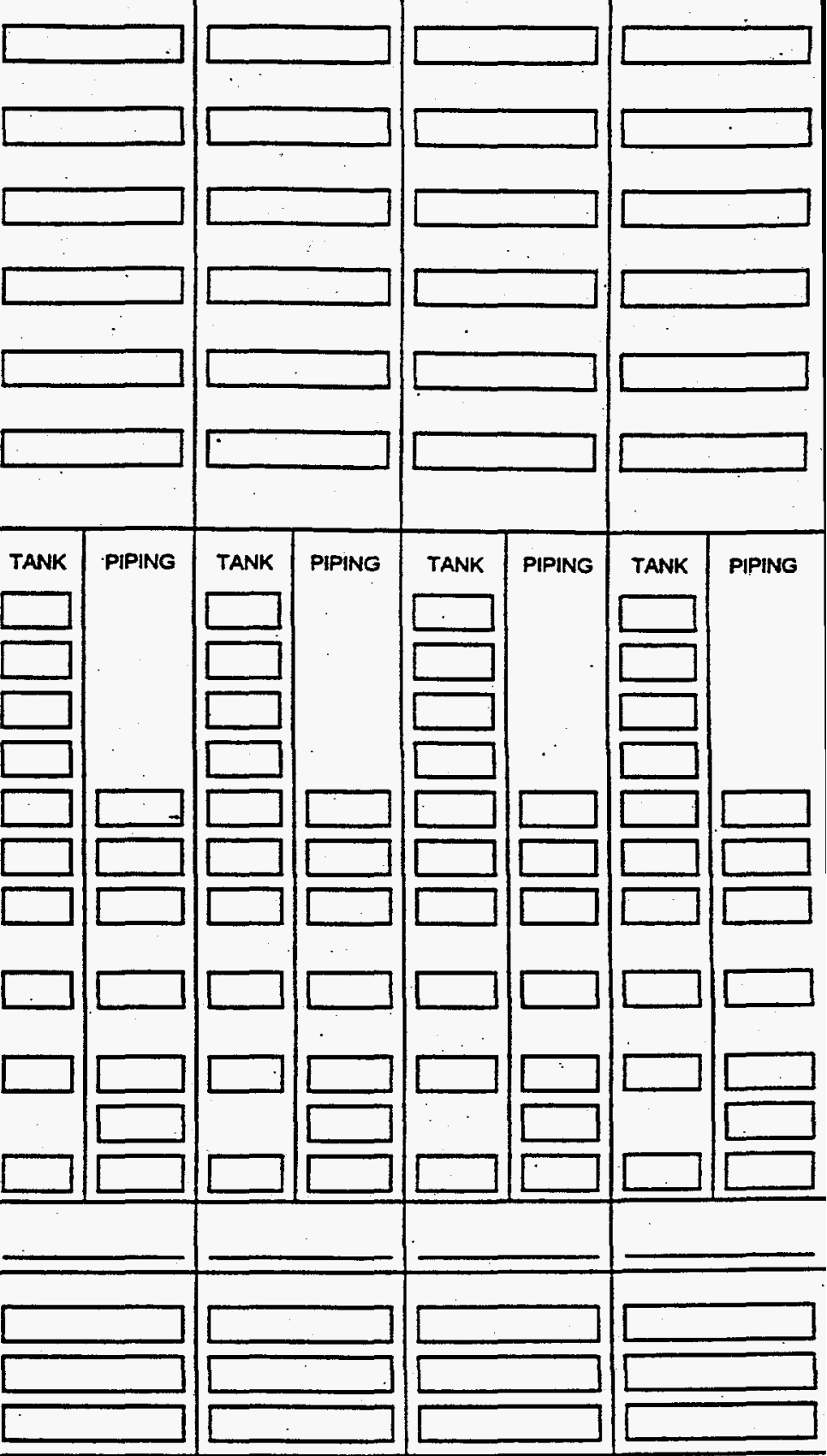

OATH: $I$ certify the information concerning installation that is provided in section $\mathrm{XI}$ is true to the best of my belief and knowledge. Installer: Not Applicable

\begin{tabular}{c}
\hline Name \\
\hline Position
\end{tabular}

Signature

Date

Company 
Page 7 of 8

Tank Identification Number

7. Substance Currently Used or Last Stored

In Greatest Quantity by volume

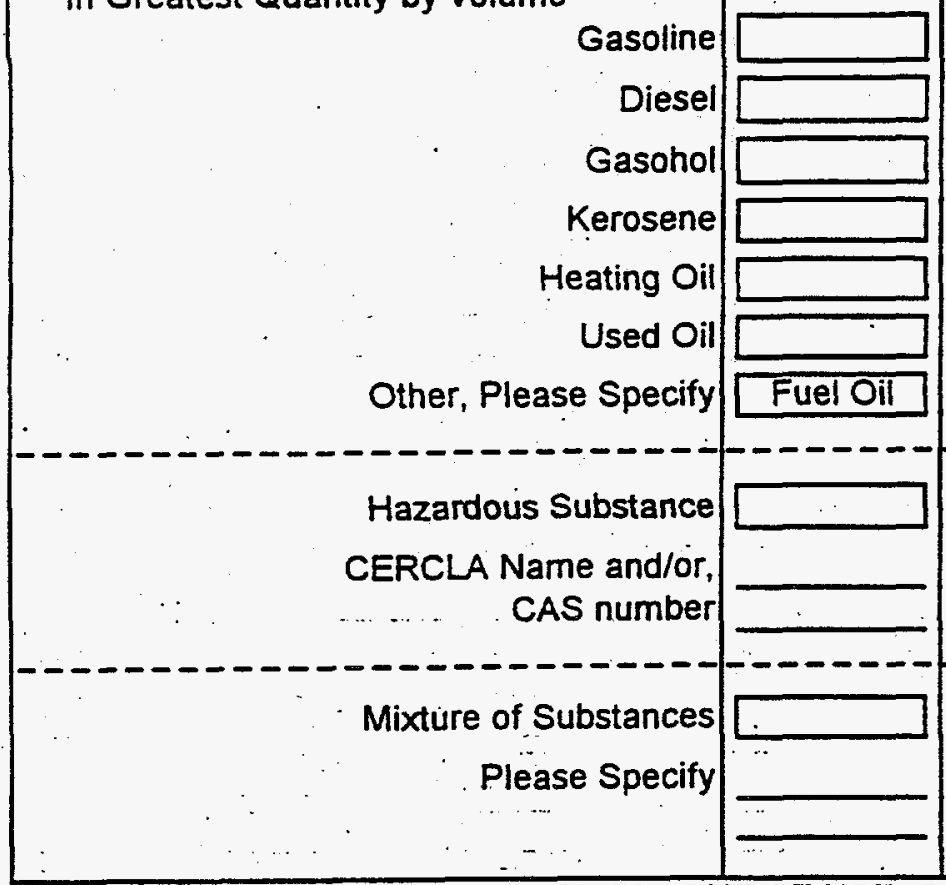

$X$. TANKS OUT OF USE, OR CHANGE IN SERVICE

1. Closing of Tank

A. Estimated Date Last Used -

B. Estimated Date Tank Closed - (mo./day/year)

C. Tank Was Removed From Ground

D. Tank Was Closed In Ground

E. Tank Filled With Inert Material Describe

\section{F. Change in Service}

2. Site Assessment Completed Evidence Of A Leak Detected
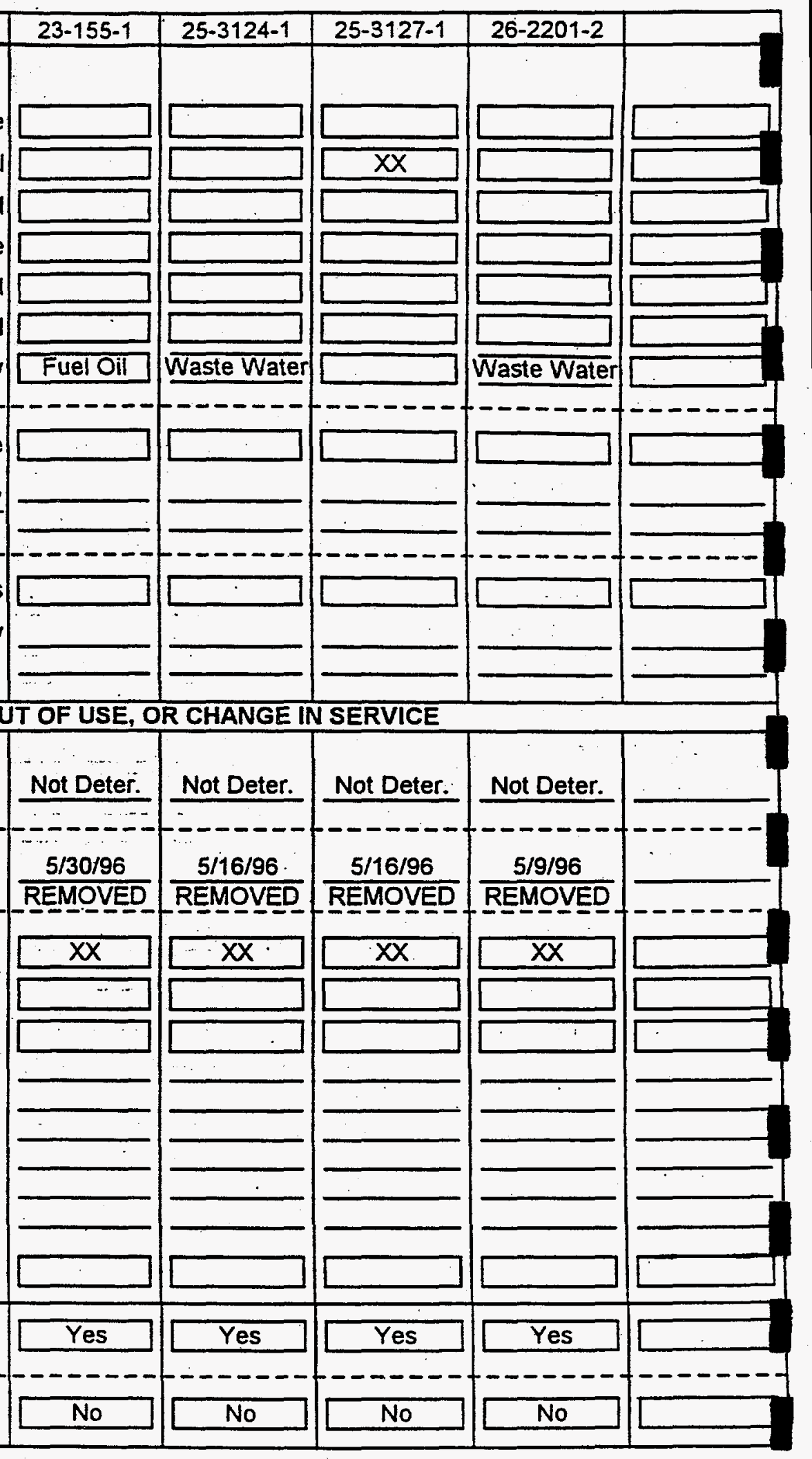


\section{APPENDIX B}

\section{DISPOSAL DOCUMENTATION}




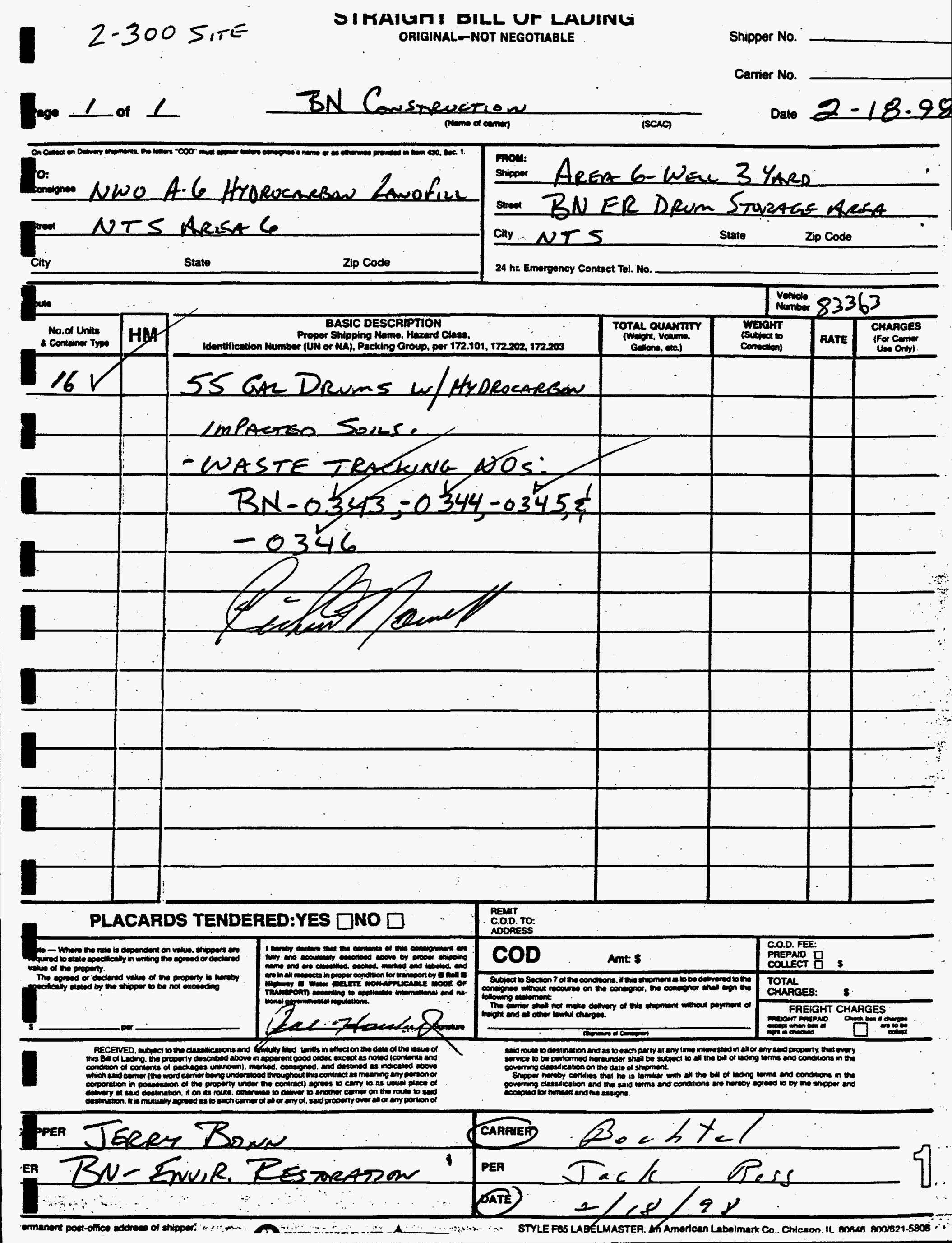



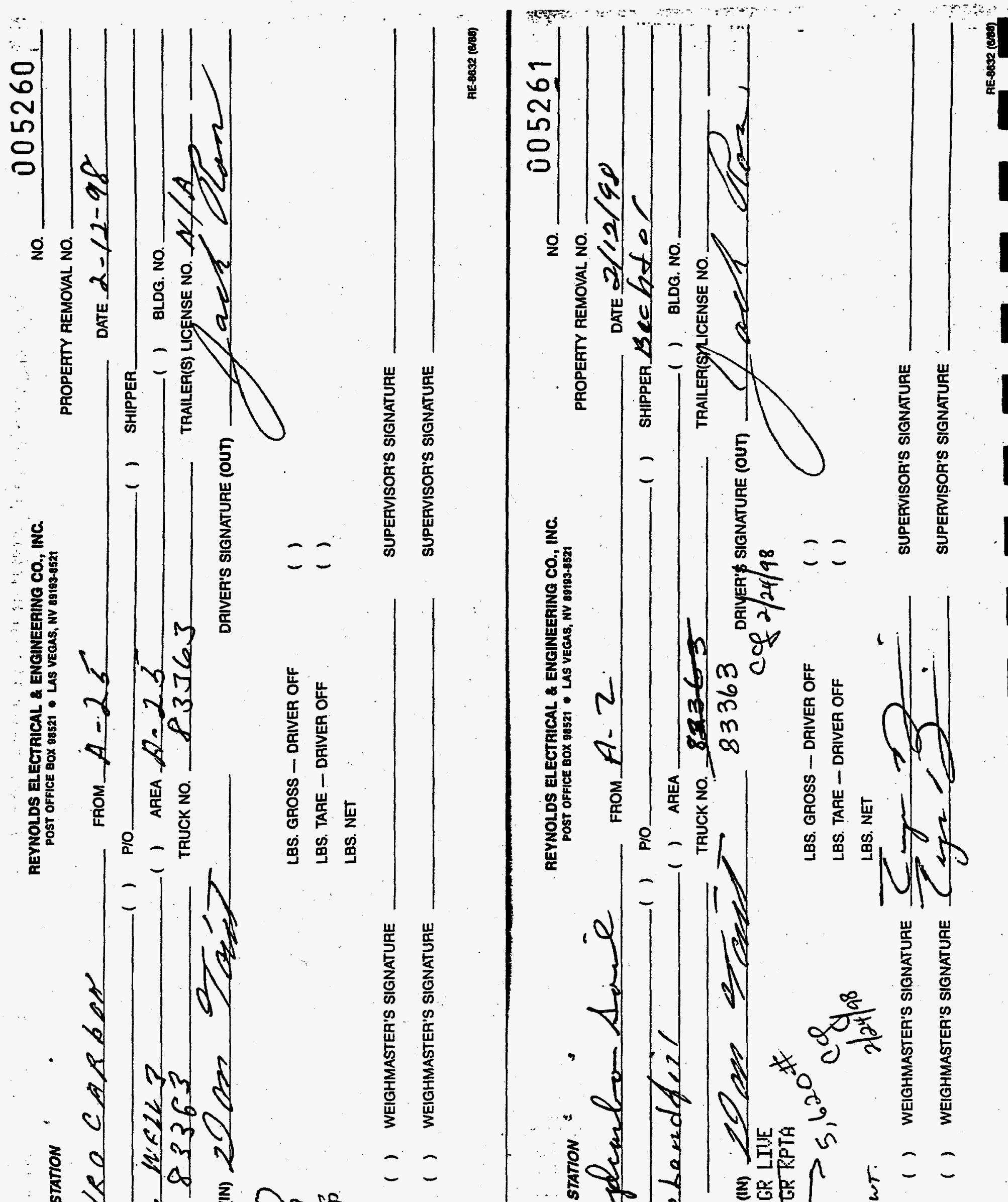

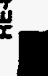

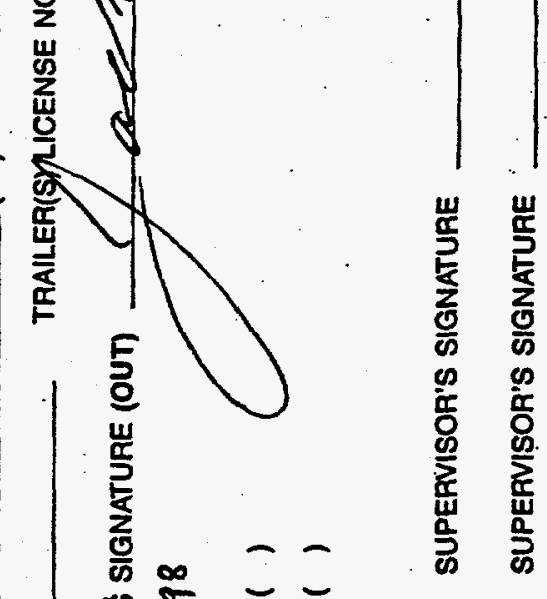

rI 3 ijo

뜬

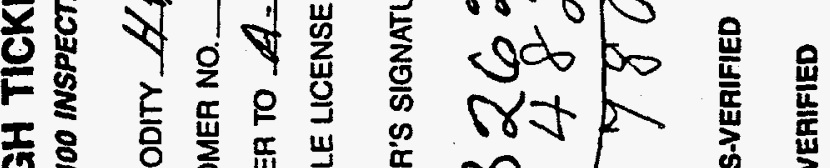

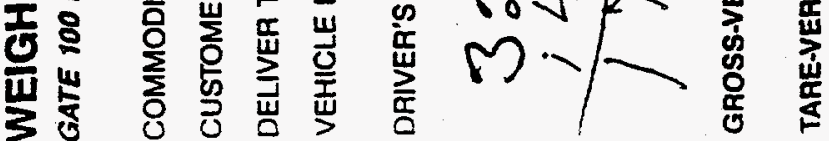

完
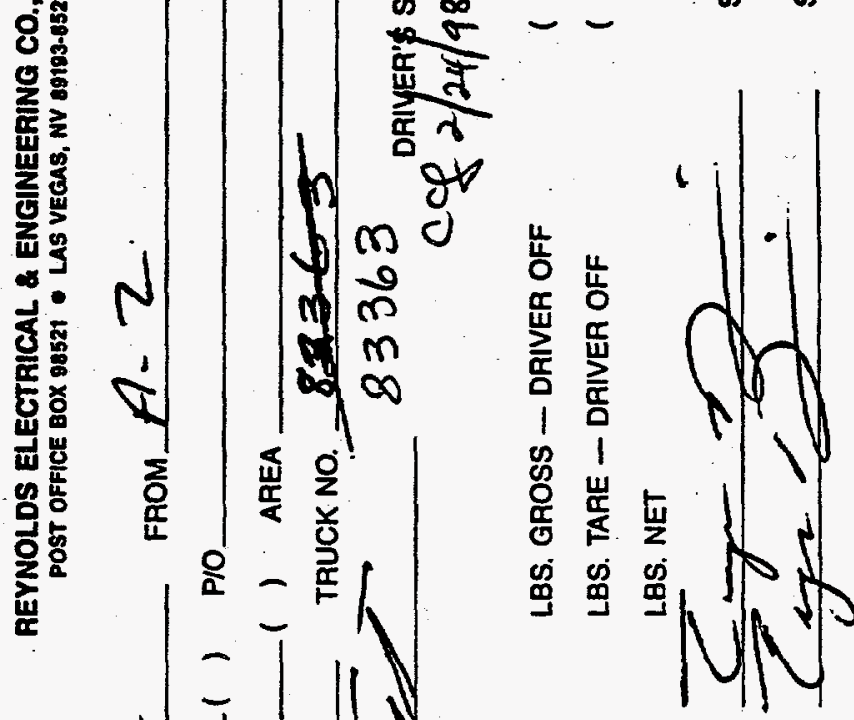
Waste Generator BN Eaveramsure Rerporesm,

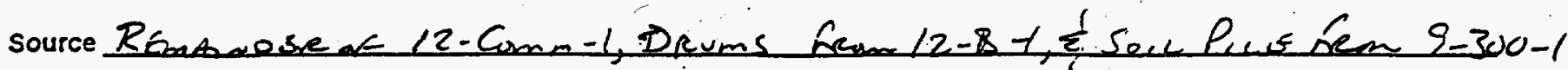

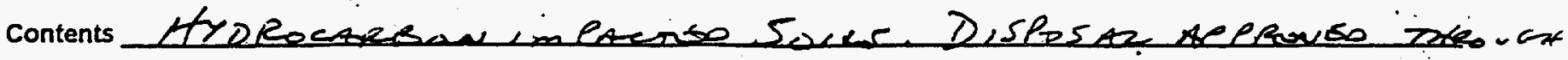
marsatec Les at ism

Method of Characterization: Process Knowledge

Sampling and Analysis

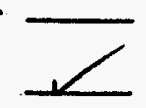

Minimization/Segregation

\section{Prohibited Wastes - The following wastes are prohibited from disposal at this site}

Radioactive Waste

Sewage sludge
Medical Waste (needles, sharps, bloody clothing)

Friable asbestos
Animal carcasses

PCBs (other than light ballasts)
Garbage (food waste)

"Free liquids"

Allowable Wastes - Construction debris containing non-putrescible and highly, inert waste consistent with the following examples
Asphalt
Insulation
Metal
Wood
Rubber
Plastic
Cloth
Pipe
Rocks Non-hydrocarton
burdened soil
Paper
Concrete
Cable and wire
Empty containers
Deconned underground and above ground tanks
Non-friable asbestos
Automobiles and Military Vehicles
To the best of my knowledge, the waste described above contains only those materials which are allowed to be disposed of at this disposal site. I have verified this through the waste characterization method identified above and a review of those prohibited and allowable waste items.

Ex+or NOS.

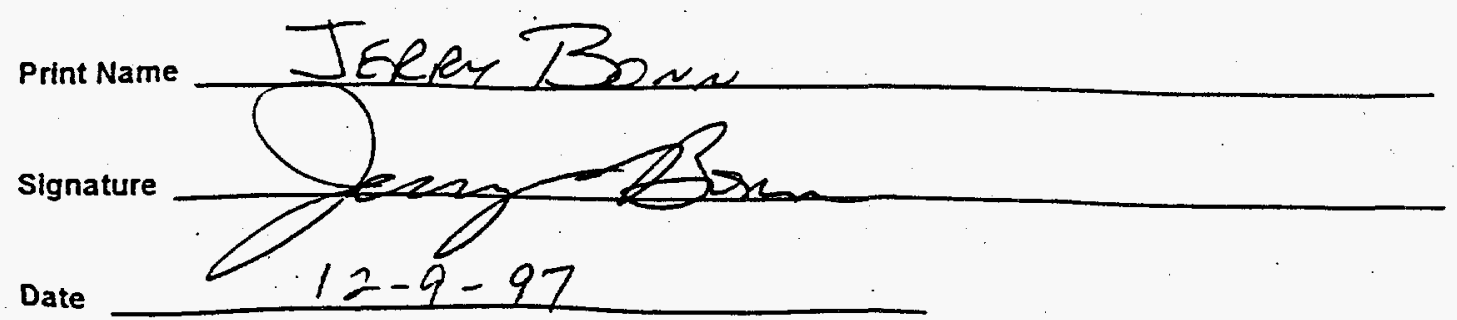




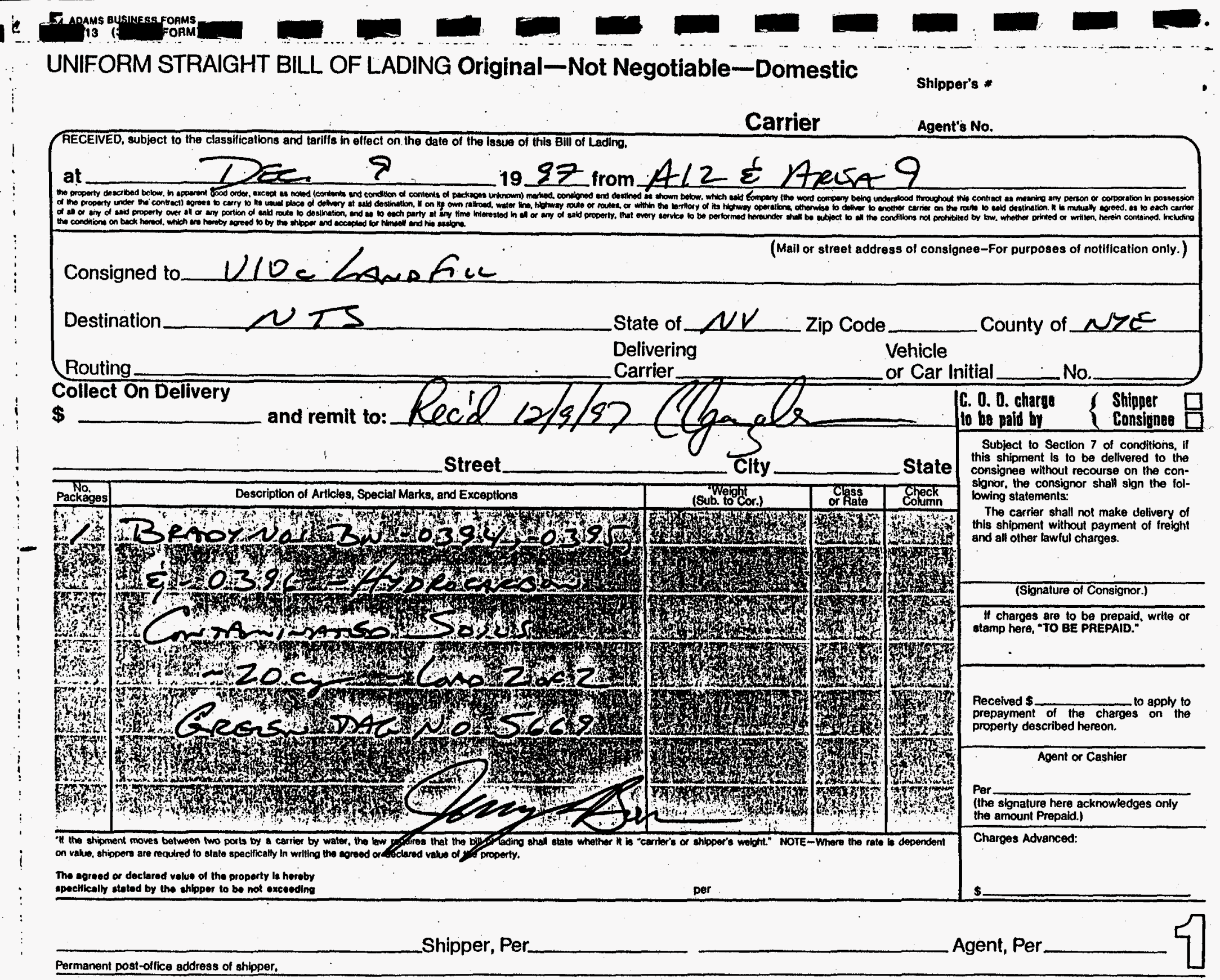

Permanent post-ollice address of stipper, 


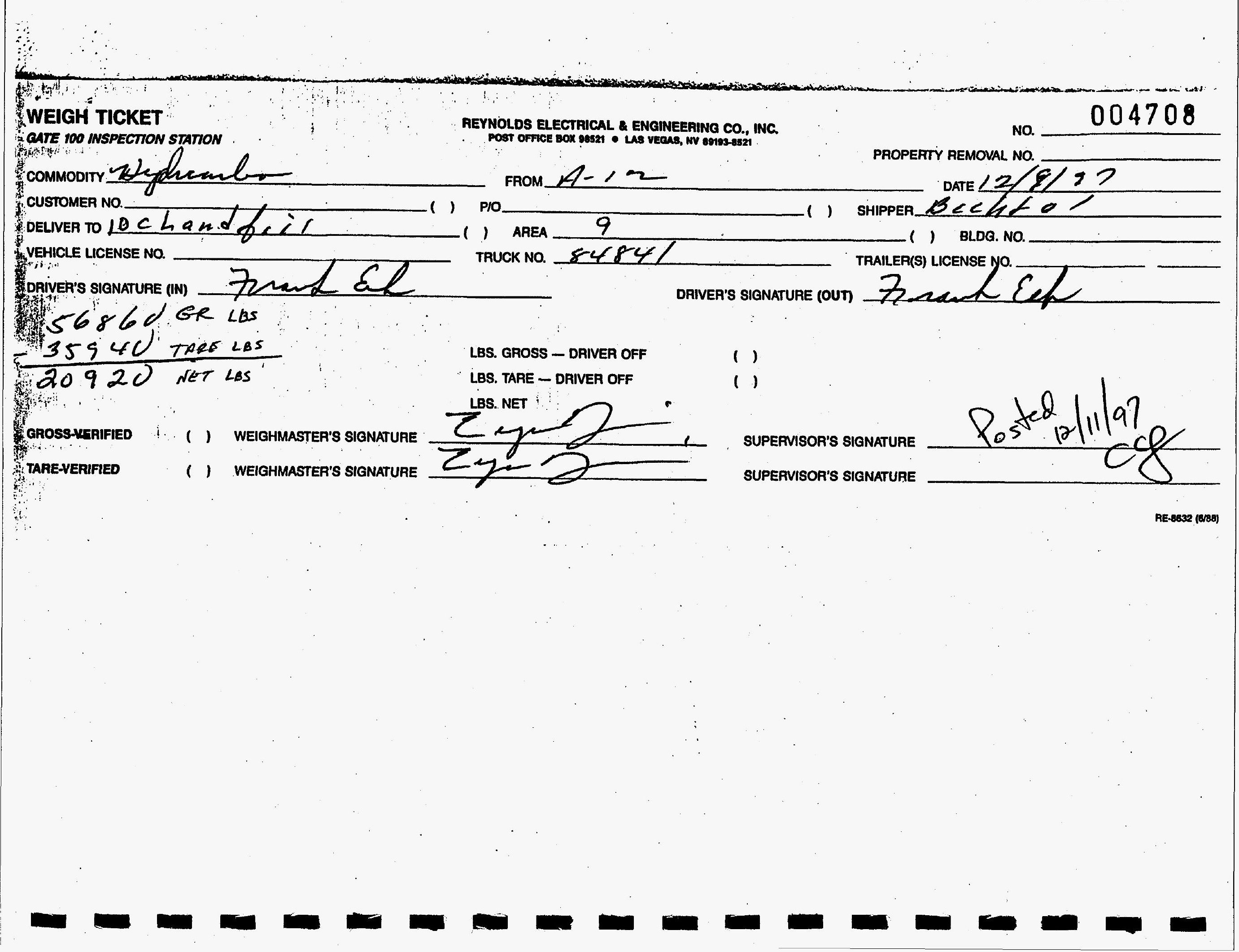


APPENDIX C

2-300-1 BOREHOLE LOGS 
PROJECT: CAU 464, CAS 02-02-03

LOCATION: Area 2 Bunker 300

BEGINNING DATE: February 4, 1998

ENDING DATE: February 4, 1998

GROUND SURFACE ELEVATION:

Approx. 4460 feet above mean sea level

BOREHOLE DIAMETER: 7 inches

BOREHOLE TOTAL DEPTH: 31 feet
GEOLOGIST/LOGGER: J.F. Bonn

DRILLING COMPANY: Bechtel Nevada

DRILL RIG MODEL: Mobile Drill B-59

DRILLING METHOD: Hollow-stem auger

SAMPLING METHOD: Split-spoon sampler (2-feet long by 2.5 -inches in diameter) driven with 140 -pound 30-inch drop hammer

BOREHOLE COMPLETION: Backfilled with sand to approx. 5 feet below ground surface and capped with bentonite and concrete

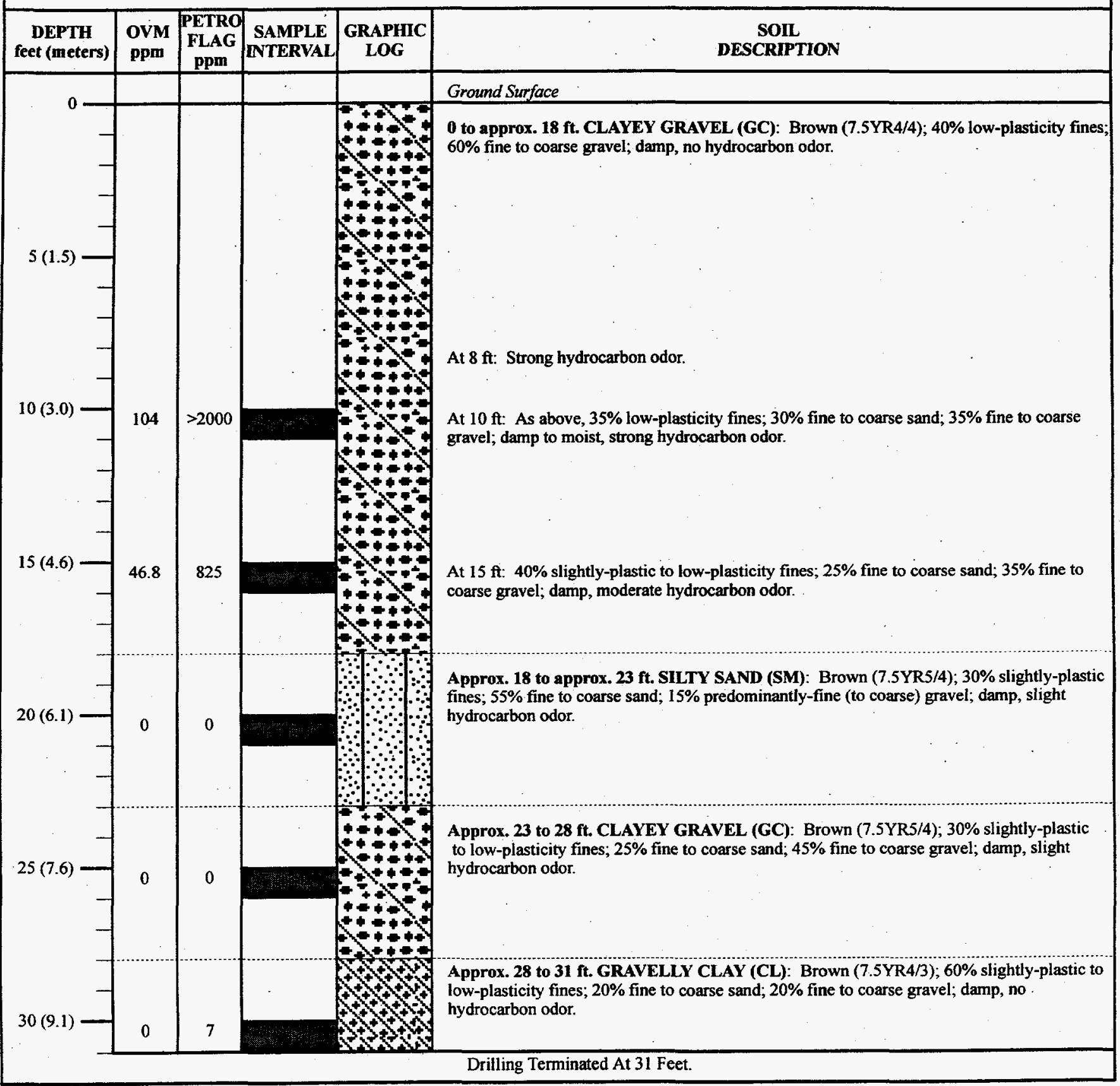


PROJECT: CAU 464, CAS 02-02-03

LOCATION: Area 2 Bunker 300

BEGINNING DATE: February 5, 1998

ENDING DATE: February 5, 1998

GROUND SURFACE ELEVATION: Approx. 4460 feet above mean sea level

BOREHOLE DIAMETER: 7 inches

BOREHOLE TOTAL DEPTH: 26 feet
GEOLOGIST/LOGGER: J.F. Bonn

DRILLING COMPANY: Bechtel Nevada

DRILL RIG MODEL: Mobile Drill B-59

DRILLING METHOD: Hollow-stem auger

SAMPLING METHOD: Split-spoon sampler (2-feet long by 2.5 -inches in diameter) driven with 140 -pound 30-inch drop hammer

BOREHOLE COMPLETION: Backfilled with sand to approx. 5 feet below ground surface and capped with bentonite and concrete

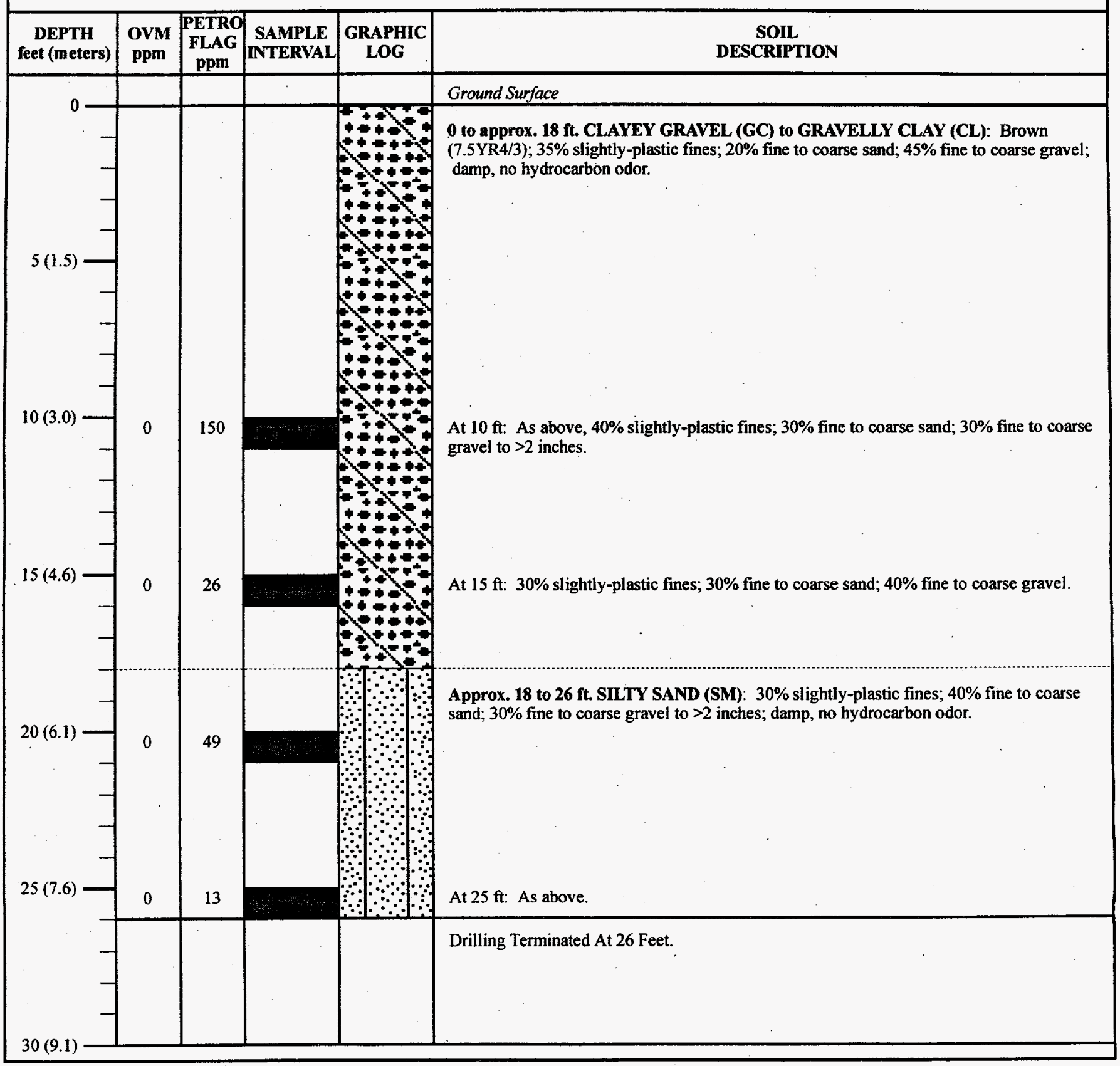


PROJECT: CAU 464, CAS 02-02-03

LOCATION: Area 2 Bunker 300

BEGINNING DATE: February 9, 1998

ENDING DATE: February 9, 1998

GROUND SURFACE ELEVATION: Approx. 4460 feet above mean sea level

BOREHOLE DIAMETER: 7 inches

BOREHOLE TOTAL DEPTH: 26 feet
GEOLOGIST/LOGGER: J.F. Bonn

DRILLING COMPANY: Bechtel Nevada

DRILL RIG MODEL: Mobile Drill B-59

DRILLING METHOD: Hollow-stem auger

SAMPLING METHOD: Split-spoon sampler (2-feet long by 2.5 -inches in diameter) driven with 140 -pound 30 -inch drop hammer

BOREHOLE COMPLETION: Backfilled with sand to approx. 5 feet below ground surface and capped with bentonite and concrete

\begin{tabular}{|c|c|c|c|c|c|}
\hline $\begin{array}{c}\text { DEPTH } \\
\text { feet (meters) }\end{array}$ & $\begin{array}{l}\text { OVM } \\
\text { ppm }\end{array}$ & $\begin{array}{l}\text { PETRO } \\
\text { FLAG } \\
\text { ppm }\end{array}$ & $\begin{array}{c}\text { SAMPLE } \\
\text { INTERVAL }\end{array}$ & $\begin{array}{l}\text { GRAPHIC } \\
\text { LOG }\end{array}$ & $\begin{array}{l}\text { SOIL } \\
\text { DESCRIPTION }\end{array}$ \\
\hline & & & . & & Ground Surface \\
\hline & & . & & & $\begin{array}{l}0 \text { to } 26 \mathrm{ft} \text {. CLAYEY GRAVEL (GC) to GRAVELLY CLAY (CL): Brown ( } 7.5 \text { YR } 4 / 3) \text {; } \\
40 \% \text { slightly-plastic fines; } 35 \% \text { fine to coarse sand; } 35 \% \text { fine to coarse gravel; damp, no } \\
\text { hydrocarbon odor. }\end{array}$ \\
\hline $5(1.5)-$ & & & & & \\
\hline $10(3.0)$ & 0 & 7 & & & $\begin{array}{l}\text { At } 10 \mathrm{ft} \text { : As above, } 40 \% \text { non-plastic fines; } 30 \% \text { fine to coarse sand; } 30 \% \text { fine to coarse } \\
\text { gravel. }\end{array}$ \\
\hline $15(4.6)$ & 0 & 4 & & & $\begin{array}{l}\text { At } 15 \mathrm{ft} \text { : As above, } 30 \% \text { slightly-plastic fines; } 30 \% \text { fine to coarse sand; } 40 \% \text { fine to coarse } \\
\text { gravel. }\end{array}$ \\
\hline $20(6.1)$ & 0 & 10 & & & At $20 \mathrm{ft}:$ As above. \\
\hline $25(7.6)$ & 0 & 0 & & & At $25 \mathrm{ft}$ : As above, proportion of gravel decreases to $20 \%$. \\
\hline & & & & & Drilling Terminated At 26 Feet. \\
\hline $30(9.1)$ & & & & & \\
\hline
\end{tabular}




\section{APPENDIX D}

LABORATORY ANALYTICAL DATA 
CLIENT: Bechtel Nevada Corp.

P.O. Box 98521, M/S NTS273

Las Vegas, NV 89193-8521

ATTN: Ted Redding

PROJECT NAME: NA

NEL ORDER ID: L9711185

PROJECT NUMBER: PO 16874

Attached are the analytical results for samples in support of the above referenced project.

Samples submitted for this project were not sampled by NEL Laboratories. Samples were received by NEL in good condition, under chain of custody on 11/20/97.

Samples were analyzed as received.

Where applicable we have included the following quality control data:

Method blank - used to demonstrate absence of contamination or interferences in the analytical process.

Laboratory Control Spike (LCS) - used to demonstrate laboratory ability to perform the method within specifications by spiking representative analytes into a clean matrix.

Surrogates - compounds added to each sample to ensure that the method requirements are met for each individual sample.

Should you have any questions or comments, please feel free to contact our Client Services department at (702) 657-1010.

Some results have been flagged as follows:

J - The batch MS and/or MSD were outside acceptance limits. The batch LCS was acceptable.
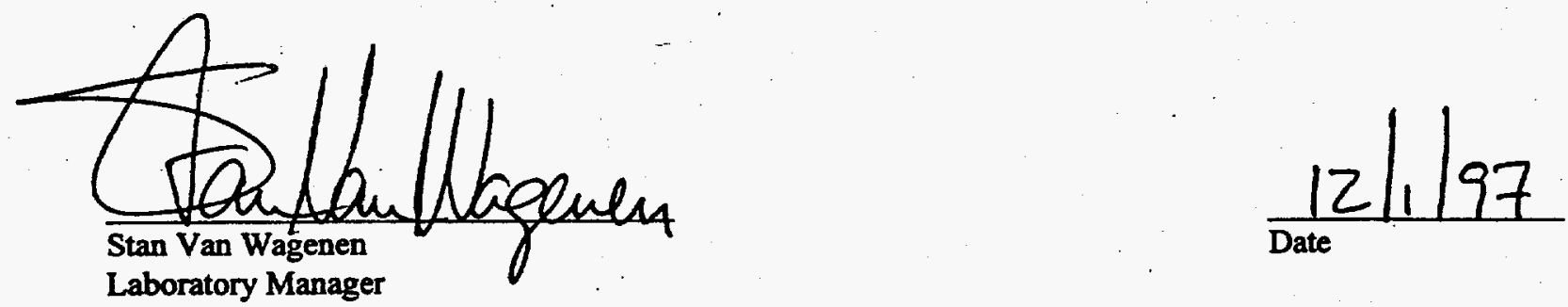

\section{CERTIFICATIONS:}

Arizona

Rene Las Yegas Burbank

AZ0520 AZ0518 AZ0325

California 1707 2002 1192

US Army Corps Certified

Certified

Certified

$\begin{array}{llll} & \text { Reno } & \text { Las Vegas } & \text { Burbank } \\ \text { Idaho } & \text { Certified } & \text { Certified } & \\ \text { Montana } & \text { Certified } & \text { Certified } & \\ \text { Nevada } & \text { NV033 } & \text { NV052 } & \text { CA084 } \\ \text { Washington } & & & \text { Certified }\end{array}$




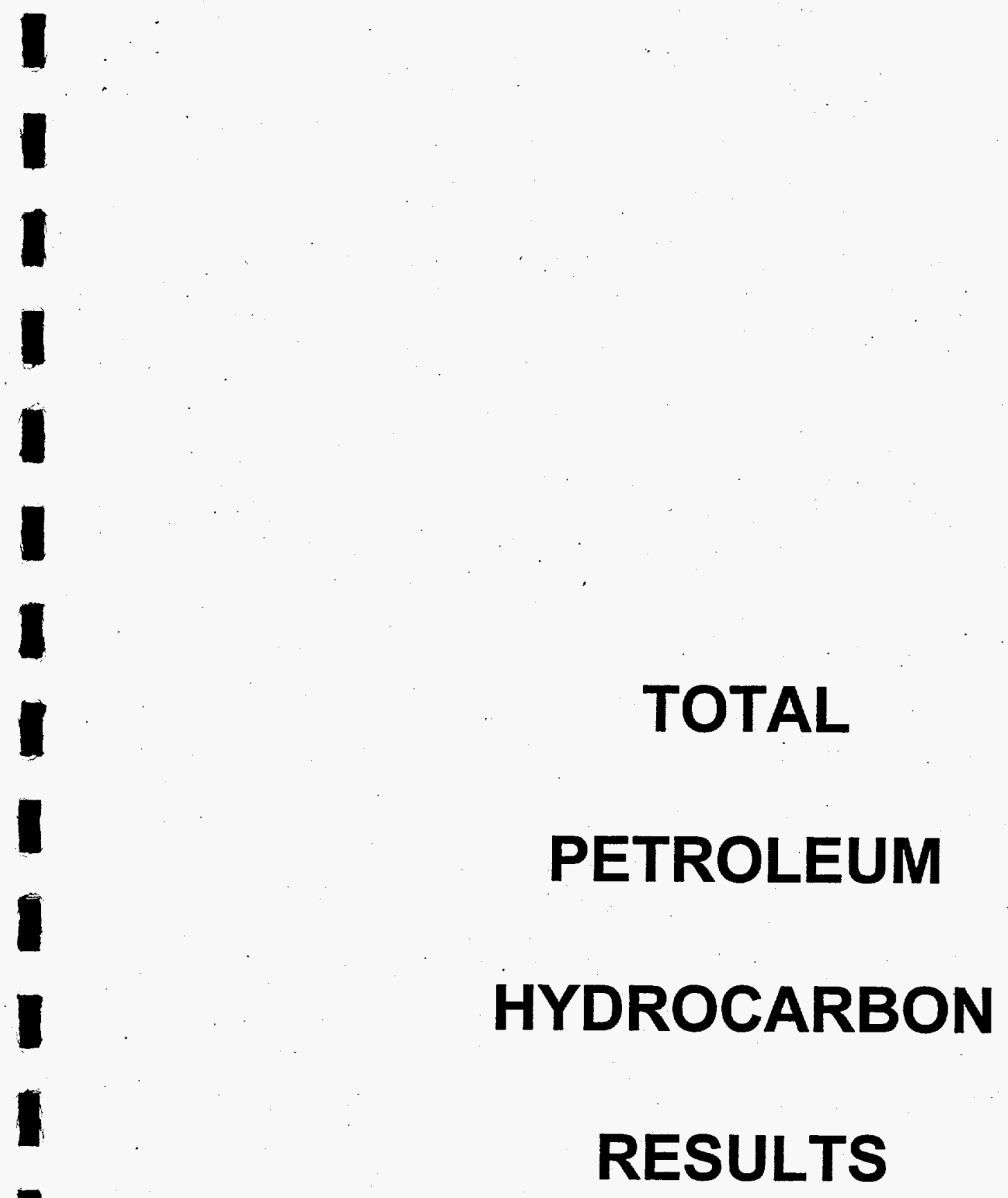


CLIENT: Bechtel Nevada Corp.

PROJECT NAME: - NA

PROJECT NUMBER: PO 16874

TEST: $\quad$ Total Extractable Petroleum Hydrocarbons by EPA Method 8015M, July 1992

METHOD: EPA 8015M

MATRX: Soil ANALYST: John

\begin{tabular}{|c|c|c|c|c|c|c|c|c|c|}
\hline $\begin{array}{l}\text { CLIENT } \\
\text { SAMPLE ID }\end{array}$ & $\begin{array}{c}\text { SAMPLE } \\
\text { DATE }\end{array}$ & $\begin{array}{c}\text { NEL } \\
\text { SAMPLE I }\end{array}$ & $\begin{array}{c}\text { RESULT } \\
\mathrm{mg} / \mathrm{kg}\end{array}$ & & $\begin{array}{c}\text { Reporting } \\
\text { Limit }\end{array}$ & $\begin{array}{l}\text { Surroge } \\
\text { Recove }\end{array}$ & & EXTRACTED & ANALYZED \\
\hline 12-B-1/East & $11 / 18 / 97$ & L9711185-0.1 & 490 & $\mathrm{~J} * *$ & 10. $\mathrm{mg} / \mathrm{kg}$ & 89 & $\%$ & $11 / 26 / 97$ & $11 / 29 / 97$ \\
\hline 12-B-/West & $11 / 18 / 97$ & L9711185-02 & 92 & $\boldsymbol{J} \mathbf{j}^{* *}$ & 10. $\mathrm{mg} / \mathrm{kg}$ & 92 & $\%$ & $11 / 26 / 97$ & $11 / 28 / 97$ \\
\hline $9-300-1 / \mathrm{S}$ & $11 / 19 / 97$ & L9711185-03 & ND & Л & 10. $\mathrm{mg} / \mathrm{kg}$ & 90 & $\%$ & $11 / 26 / 97$ & $11 / 28 / 97$ \\
\hline 12-Comm-1/S9 & $11 / 19 / 97$ & L9711185-04 & ND & л & $10 . \mathrm{mg} / \mathrm{kg}$ & 93 & $\%$ & $11 / 26 / 97$ & $11 / 29 / 97$ \\
\hline 12-Comm-1/N9 & $11 / 19 / 97$ & L9711185-05 & ND & $\boldsymbol{\Omega}$ & 10. $\mathrm{mg} / \mathrm{kg}$ & 88 & $\%$ & $11 / 26 / 97$ & $11 / 29 / 97$ \\
\hline
\end{tabular}

** Diesel Range Organics (C12 to C32).

Note: The reporting limit for Oil Range Organics in soil is $50 \mathrm{mg} / \mathrm{kg}$.

QUALITY CONTROL DATA (Total for Gas and Diesel Range):

Sample ID

Blank, 971126stph -BLK

LCS, 971126stph - LCS

MS, 971126 stph - MS

MSD, 971126stph - MSD

Result Acceptable Range Surrogate Recovery* Sample Number

$\begin{array}{lccccc}\text { ND } & < & 10 . \mathrm{mg} / \mathrm{kg} & 92 & \% & \text { NA } \\ 89 & \% & 55 & -102 \% & 99 \% & \text { NA } \\ 154 \% & 55 & -102 \% & 102 \% & \text { L9711185-01 } \\ 211 \% & 55-102 \% & 118 \% & \text { L9711185-01 }\end{array}$

ND - Not Detected

- Surrogate used was Octacosane, acceptance limits 70-130\%.

This report shall not be reproduced except in full, without the written approval of the laboratory. 


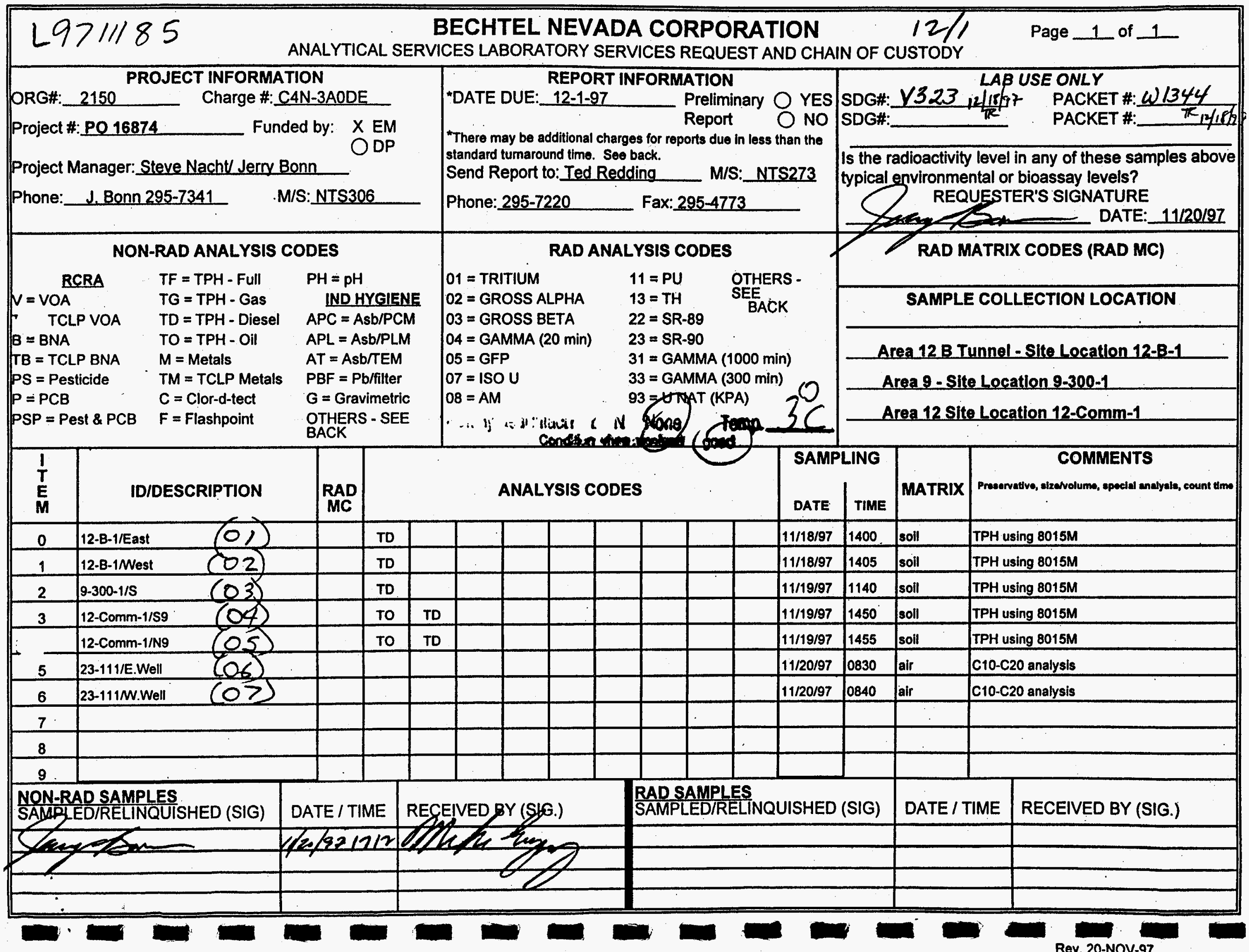


SAMPLE DELIVERY GROUP: V323

LABORATORY: NEL

EINAL REPORT RECEIVED: $12 / 12 / 97$

DATE REVIEWED: $12 / 23 / 97$

TPH - DIESEL / OIL:

MATRIX: SOIL

ARE TPH DIESELOIL DATA ACCEPTABLE: YES
CLIENT: RP - JERRY BONN

REVIEWED BY:

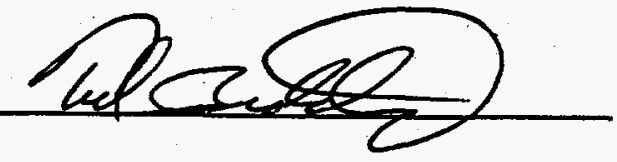

1. QC SAMPLES ACCEPTABLE

2. MATRIX SPIKE ACCEPTABLE

3. METHOD BLANK ACCEPTABLE

4. HOLDING TIMES ACCEPTABLE ARE CRITERIA MET

4. HOLDING TMES ACCETABLE

a. Date Sampled:
b. Date ASL Received:
c. Date Contract Lab Received:
d. Date Extracted:
e. Date Analyzed:

5. CALCULATIONS ACCEPTABLE:

6. CORRECT CONC. UNITS USED:

7. FORMS ACCEPTABLE:

8. CHAIN-OF-CUSTODY AGREES:

\begin{tabular}{|c|c|c|}
\hline & \#DAYS & ACCEPTABLE \\
\hline 11/19/97 & 0 & 0 \\
\hline N/A & N/A & 1 \\
\hline 11/20/97 & 1 & 5 \\
\hline 11/26/97 & 7 & 14 \\
\hline 11/29/97 & 3 & 40 \\
\hline
\end{tabular}

COMMENTS: Method associated quality assurance and control criteria were met. Sample 12-B-1Mest is identified as 12-B-Mest in the report. The multipeak chromatograms produced from analyses of samples 12-B-1/East and 12-B-1Mest did not identically match the lab's diesel or oil standards, but eluted between them, overlapping much of the diesel elution range. The responses were quantitated using the diesel calibration and should be considered estimates of the hydrocarbon concentration. Sample 12-B-1/East was used for the matrix spike and matrix spike duplicate. Recoveries were outside the upper control limit. attributed to matrix effects. 


\section{CLIENT: Bechtel Nevada}

P.O. Box 98521, M/S NTS273

Las Vegas, NV 89193-8521

ATTN: Ted Redding

PROJECT NAME: Area $2 \& 25$

PROJECT NUMBER: 2150

Attached are the analytical results for samples in support of the above referenced project.

Samples submitted for this project were not sampled by NEL Laboratories. Samples were received by NEL in good condition, under chain of custody on 2/6/98.

Samples were analyzed as received.

Where applicable we have included the following quality control data:

Method blank - used to demonstrate absence of contamination or interferences in the analytical process. Laboratory Control Spike (LCS) - used to demonstrate laboratory ability to perform the method within specifications by spiking representative analytes into a clean matrix.

Surrogates - compounds added to each sample to ensure that the method requirements are met for each individual sample.

Should you have any questions or comments, please feel free to contact our Client Services department at (702) 657-1010.

Mirhas limadat for S.V.W.

Stan Van Wagenen

Laboratory Manager

\section{CERTIFICATIONS:}

\begin{tabular}{llll}
\hline & Reno & \multicolumn{1}{c}{ Las Vegas } & Burbank \\
\cline { 2 - 4 } Arizona & AZ0520 & AZ0518 & AZ0325 \\
California & 1707 & 2002 & 1192 \\
$\begin{array}{l}\text { US Army Corps } \\
\text { of Engineers }\end{array}$ & Certified & Certified & Certified \\
& & &
\end{tabular}

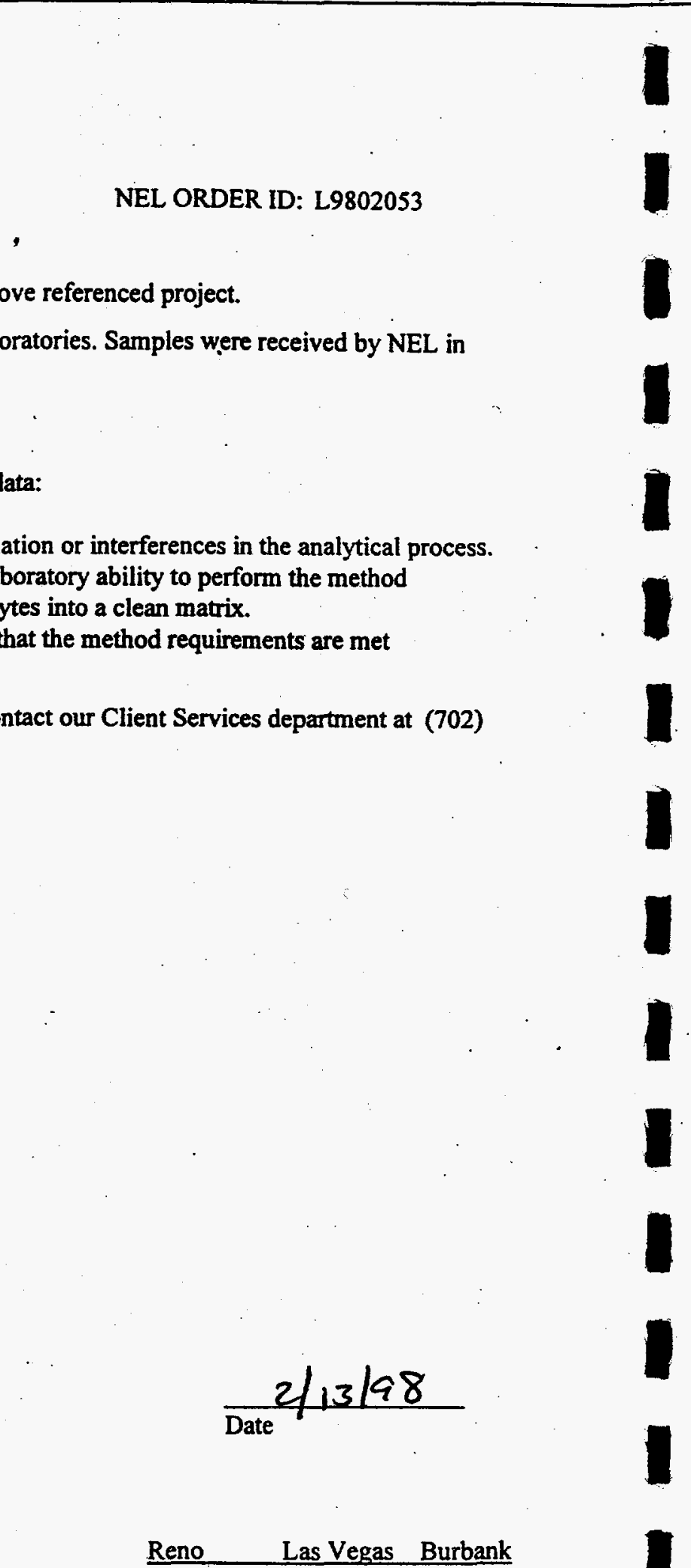


CLIENT: Bechtel Nevada

PROJECT NAME: Area $2 \& 25$

PROJECT NUMBER: 2150
CLIENT ID: 2-300/B1 @ 15'

DATE SAMPLED: $2 / 4 / 98$

NEL SAMPLE ID: L9802053-04

TEST: Total Extractable Petroleum Hydrocarbons Fuel Finger Print by EPA Method 8015M, July 1992

MATRIX: Solid

DILUTION: 2

PARAMETER

Diesel Range (C12-C22)

Total
EXTRACTED: $2 / 6 / 98$

ANALYZED: $2 / 9 / 98$
ANALYST: Suzanne

\begin{tabular}{cc}
\multicolumn{2}{c}{ Result } \\
\hline 230 & $\mathrm{mg} / \mathrm{Kg}$ \\
230 & $\mathrm{mg} / \mathrm{Kg}$
\end{tabular}

Reporting

Limit

20. $\mathrm{mg} / \mathrm{Kg}$

20. $\mathrm{mg} / \mathrm{Kg}$

This report shall not be reproduced except in full, without the written approval of the laboratory. 
CLIENT: Bechtel Nevada

PROJECT NAME: Area $2 \& 25$

PROJECT NUMBER: 2150
CLIENT ID: 2-300/B1 @ 18'

DATE SAMPLED: $2 / 4 / 98$

NEL SAMPLE ID: L9802053-05

TEST: Total Extractable Petroleum Hydrocarbons Fuel Finger Print by EPA Method 8015M, July 1992 MATRIX: Solid EXTRACTED: 2/6/98

DILUTION: 2 ANALYZED: $2 / 9 / 98$

ANALYST: Suzanne

PARAMETER

Diesel Range (C12-C22)

Total

\begin{tabular}{cc}
\multicolumn{3}{c}{ Result } \\
\hline 370 & $\mathrm{mg} / \mathrm{Kg}$ \\
$\mathbf{3 7 0}$ & $\mathrm{mfg} / \mathrm{Kg}$
\end{tabular}

Reporting Limit

20. $\mathrm{mg} / \mathrm{Kg}$

20. $\mathrm{mg} / \mathrm{Kg}$ 
CLIENT: Bechtel Nevada

PROJECT NAME: Area $2 \& 25$

PROJECT NUMBER: 2150
CLIENT ID: $2-300 / B 1 @ 20^{\prime}$

DATE SAMPLED: $2 / 4 / 98$

NEL SAMPLE ID: L9802053-06

TEST: Total Extractable Petroleum Hydrocarbons Fuel Finger Print by EPA Method 8015M, July 1992 MATRIX: Solid EXTRACTED: 2/6/98 DILUTION: 2 ANALYZED: $2 / 9 / 98$

ANALYST: Suzanne

PARAMETER

Diesel Range (C12-C22)

Total

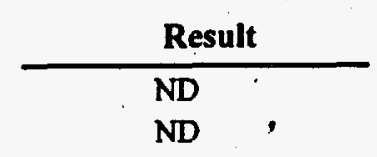

\begin{tabular}{c}
$\begin{array}{c}\text { Reporting } \\
\text { Limit }\end{array}$ \\
\hline $20 . \mathrm{mg} / \mathrm{Kg}$ \\
$20 . \mathrm{mg} / \mathrm{Kg}$
\end{tabular}




\section{NEL LABORATORIES}

CLIENT: Bechtel Nevada

PROJECT NAME: Area $2 \& 25$

PROJECT NUMBER: 2150
CLIENT ID: 2-300/B1 @ 25'

DATE SAMPLED: $2 / 4 / 98$

NEL SAMPLE ID: L9802053-07

TEST: Total Extractable Petroleum Hydrocarbons Fuel Finger Print by EPA Method 8015M, July 1992

MATRIX: Solid

DILUTION: 2

PARAMETER

Diesel Range (C12-C22)
EXTRACTED: $2 / 6 / 98$

ANALYZED: $2 / 9 / 98$

ANALYST: Michael

Result

ND

$\frac{\begin{array}{c}\text { Reporting } \\ \text { Limit }\end{array}}{20 . \mathrm{mg} / \mathrm{Kg}}$


CLIENT: Bechtel Nevada

PROJECT NAME: Area 2 \& 25

PROJECT NUMBER: 2150
CLIENT ID: 2-300/B1 @ 30'

DATE SAMPLED: $2 / 4 / 98$

NEL SAMPLE ID: L9802053-08

TEST: Total Extractable Petroleum Hydrocarbons Fuel Finger Print by EPA Method 8015M, July 1992

MATRIX: Solid

DILUTION: 2
EXTRACTED: $2 / 6 / 98$

ANALYZED: $2 / 9 / 98$
ANALYST: Michael
PARAMETER

Diesel Range (C12-C22)
Result

ND
Reporting

Limit

20. $\mathrm{mg} / \mathrm{Kg}$ 
CLIENT: Bechtel Nevada

PROJECT NAME: Area $2 \& 25$

PROJECT NUMBER: 2150
CLIENT ID: 2-300/B2 @ 10'

DATE SAMPLED: $2 / 5 / 98$

NEL SAMPLE ID: L9802053-09

TEST: Total Extractable Petroleum Hydrocarbons Fuel Finger Print by EPA Method 8015M, July 1992

MATRIX: Solid

DILUTION: 2

PARAMETER

Diesel Range (C12-C22)
EXTRACTED: 2/6/98

ANALYZED: $2 / 9 / 98$
ANALYST: Michael

$\frac{\text { Result }}{\text { ND }}$

Reporting Limit 20. $\mathrm{mg} / \mathrm{Kg}$ 
CLIENT: Bechtel Nevada

PROJECT NAME: Area $2 \& 25$

PROJECT NUMBER: 2150
CLIENT ID: 2-300/B2@ 15'

DATE SAMPLED: $2 / 5 / 98$

NEL SAMPLE ID: L9802053-10

TEST: Total Extractable Petroleum Hydrocarbons Fuel Finger Print by EPA Method 8015M, July 1992

MATRIX: Solid

EXTRACTED: $2 / 6 / 98$

DILUTION: 2

ANALYZED; $2 / 9 / 98$

ANALYST: Michael

PARAMETER

Diesel Range (C12-C22)

$\frac{\text { Result }}{\text { ND }}$


CLIENT: Bechtel Nevada

PROJECT NAME: Area 2 \& 25

PROJECT NUMBER: 2150
CLIENT ID: $2-300 / B 2 @ 20 '$

DATE SAMPLED: $2 / 5 / 98$

NEL SAMPLE ID: L9802053-11

TEST: Total Extractable.Petroleum Hydrocarbons Fuel Finger Print by EPA Method 8015M, July 1992

MATRIX: Solid

DILUTION: 2

\section{PARAMETER}

Diesel Range (C12-C22)
EXTRACTED: 2/6/98

ANALYZED: $2 / 9 / 98$

$\frac{\text { Result }}{\text { ND }}$

ANALYST: Michael

Reporting

Limit

20. $\mathrm{mg} / \mathrm{Kg}$ 
CLIENT: Bechtel Nevada

PROJECT NAME: $\quad$ Area $2 \& 25$

PROJECT NUMBER: 2150
CLIENT ID: 2-300/B2 @ 25'

DATE SAMPLED: $2 / 5 / 98$

NEL SAMPLE ID: $\quad$ L9802053-12

TEST: Total Extractable Petroleum Hydrocarbons Fuel Finger Print by EPA Method 8015M, July 1992

MATRIX: Solid EXTRACTED: $2 / 6 / 98$

DILUTION: 2 ANALYZED: $2 / 9 / 98$

ANALYST: Michael

PARAMETER

Diesel Range (C12-C22)

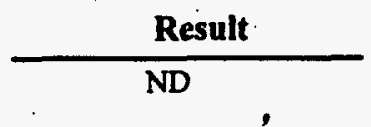

Reporting

Limit

. 20. $\mathrm{mg} / \mathrm{Kg}$ 


\section{NEL LABORATORIES}

CLIENT: Bechtel Nevada

PROJECT NAME: Area $2 \& 25$

PROJECT NUMBER: 2150
CLIENT ID: Method Blank

DATE SAMPLED: NA

NEL SAMPLE ID: 980206tphs-ase-BK

TEST: Total Extractable Petroleum Hydrocarbons Fuel Finger Print by EPA Method 8015M, July 1992 MATRIX: Solid

EXTRACTED: $2 / 6 / 98$

ANALYZED: $2 / 9 / 98$

ANALYST: Michael

PARAMETER

Diesel Range (C12-C22)

$\frac{\text { Result }}{\text { ND }}$

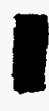

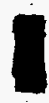

Reporting

Limit

$20 \mathrm{mg} / \mathrm{Kg}$ 


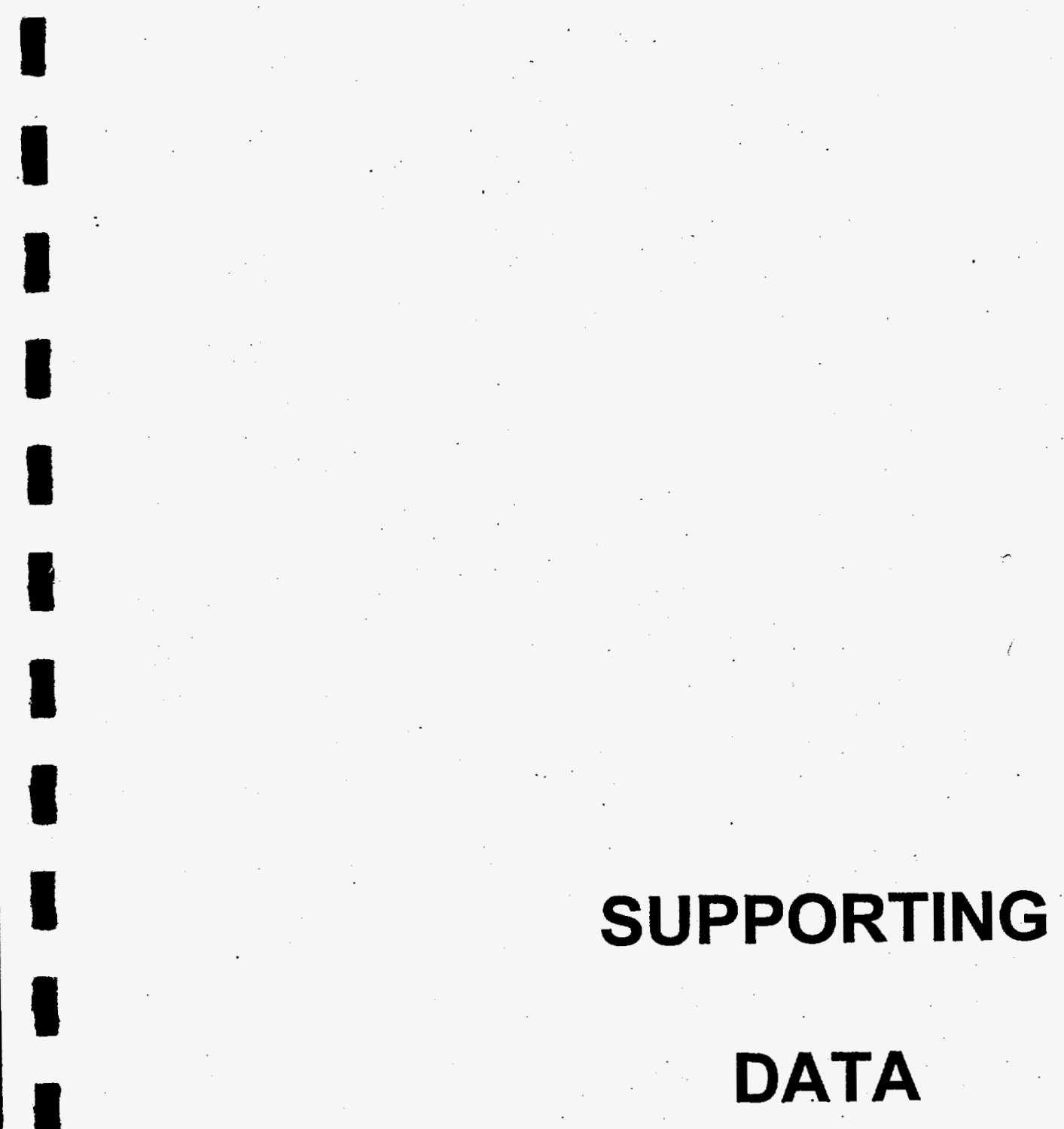


SAMPLE DELIVERY GROUP: SDG V352 CLIENT: RP - JERRY BONN

LABORATORY: NEL

EINAL REPORT RECEIVED: 03/16/98

DATE REVIEWED: 03/24/98.

REVIEWED BY:

TPH - DIESEL:

MATRIX: SOIL

ARE TPH DATA ACCEPTABLE: YES.

ARE CRITERIA MET

1. QC SAMPLES ACCEPTABLE

2. MATRIX SPIKE ACCEPTABLE

3. METHOD BLANK ACCEPTABLE

4. HOLDING TIMES ACCEPTABLE

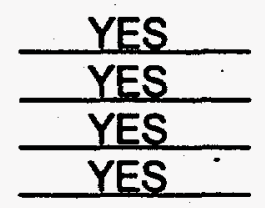

a. Earliest Date Sampled:

2/2/98

\#DAYS

ACCEPTABLE

b. Date ASL Received:

N/A

0

0

c. Date Contract Lab Received:

2/6/98

N/A

1

d. Date Extracted:

4

5

2/6/98

4

14

e. Date Analyzed:

2/9/98

3

40

5. CALCULATIONS ACCEPTABLE:

6. CORRECT CONC. UNITS USED:

7. FORMS ACCEPTABLE::

8. CHAIN-OF-CUSTODY AGREES:

\begin{tabular}{c}
$\frac{\text { YES }}{\text { YES }}$ \\
\hline YES \\
\hline YES \\
\hline
\end{tabular}

COMMENTS: Method associated quality assurance and control criteria were met. Preliminary results were transmitted to the client on $2 / 10$ and $2 / 17 / 98$. 


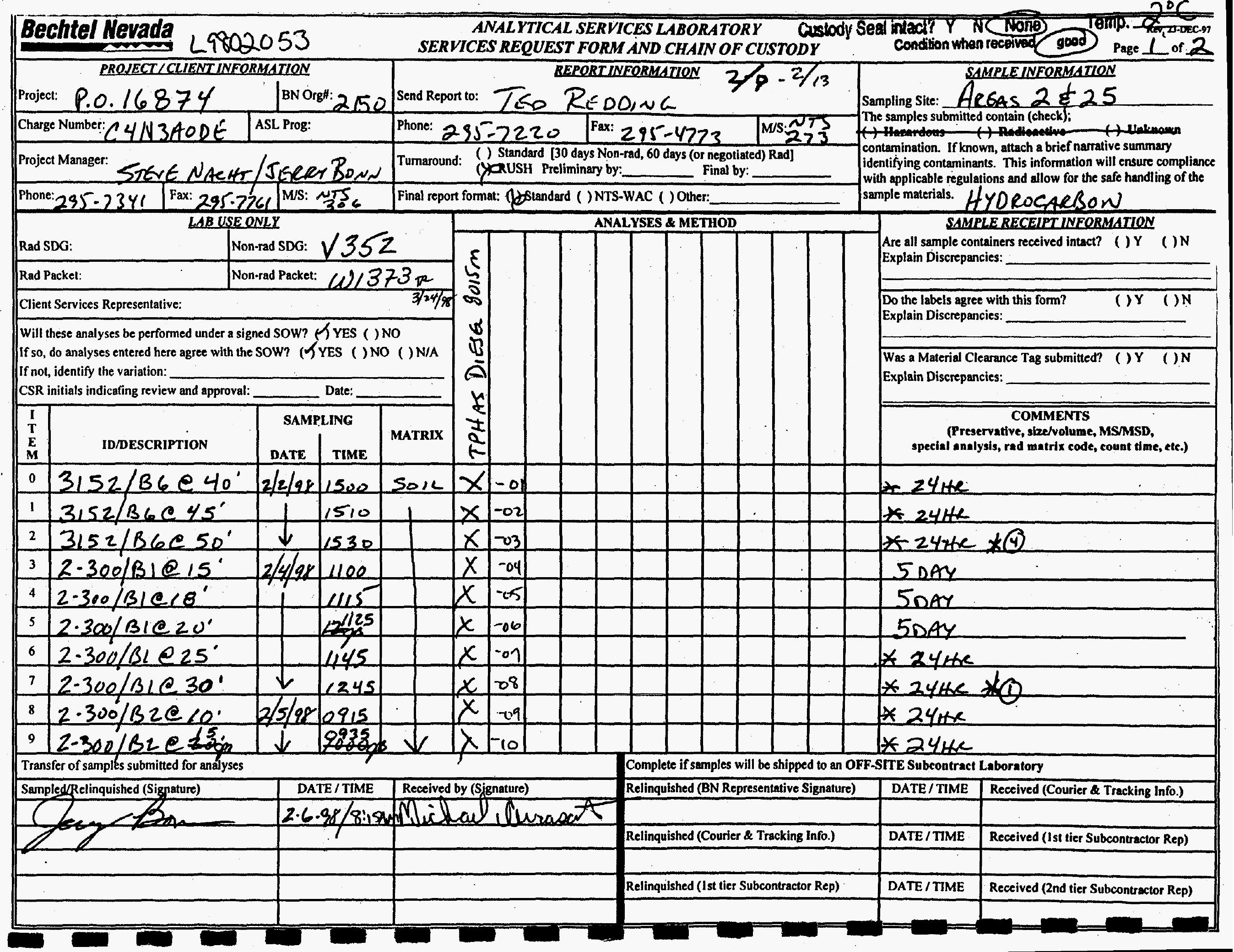




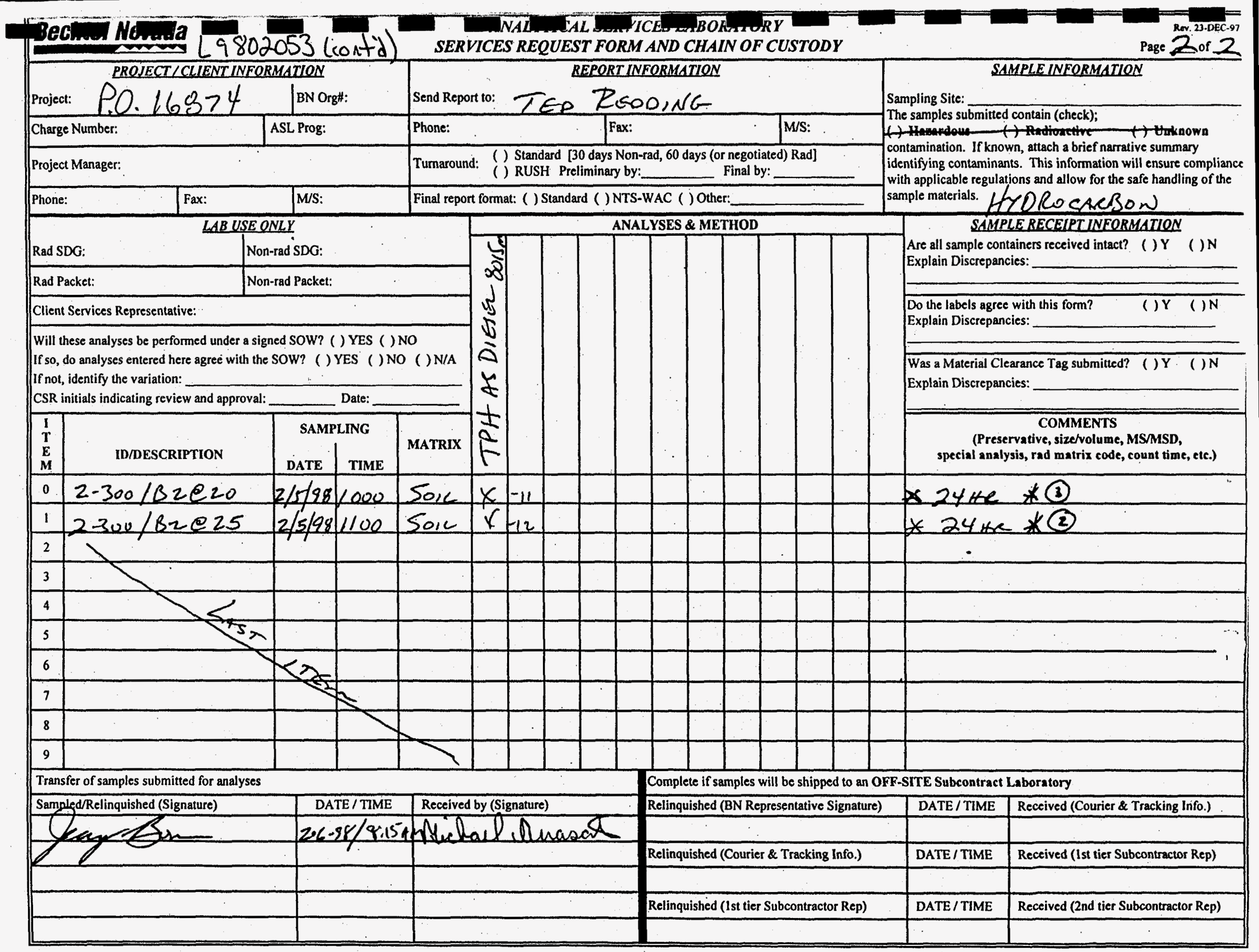


CLIENT: Bechtel Nevada

P.O. Box 98521, M/S NTS273

Las Vegas, NV 89193-8521

ATTN: Ted Redding

PROJECT NAME: NA

NEL ORDER ID: L9802126

PROJECT NUMBER: 2151

Attached are the analytical results for samples in support of the above referenced project.

Samples submitted for this project were not sampled by NEL Laboratories. Samples were received by NEL in good condition, under chain of custody on 2/13/98.

Samples were analyzed as received.

Where applicable we have included the following quality control data:

Method blank - used to demonstrate absence of contamination or interferences in the analytical process. Laboratory Control Spike (LCS) - used to demonstrate laboratory ability to perform the method within specifications by spiking representative analytes into a clean matrix.

Surrogates - compounds added to each sample to ensure that the method requirements are met for each individual sample.

Should you have any questions or comments, please feel free to contact our Client Services department at (702) 657-1010.
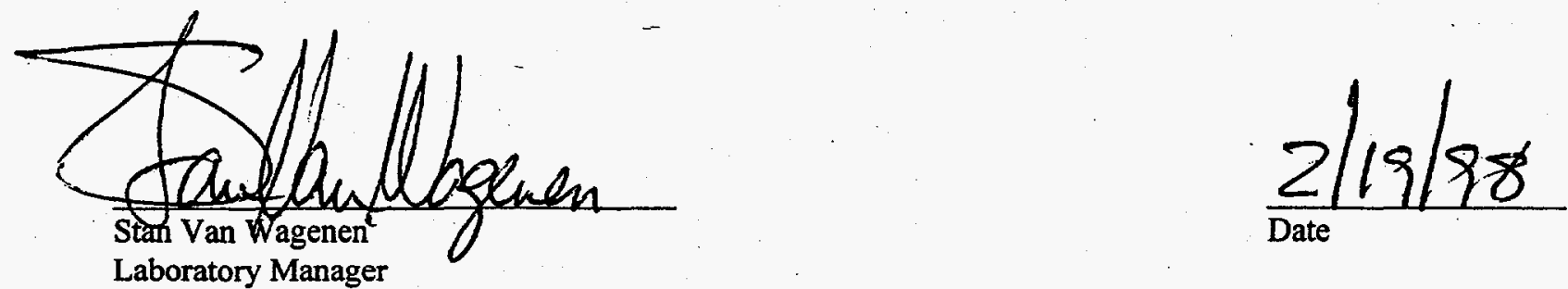

CERTIFICATIONS:

\begin{tabular}{|c|c|c|c|}
\hline & Reno & Las Vega & Burbank \\
\hline Arizol & AZ0520 & AZ0518 & AZ0325 \\
\hline Califo & 1707 & 2002 & 1192 \\
\hline $\begin{array}{l}\text { US Army Corps } \\
\text { of Engineers }\end{array}$ & Certified & Certified & Certified \\
\hline
\end{tabular}

\begin{tabular}{llll} 
& Reno & Las Vegas & Burbank \\
\cline { 2 - 4 } Idaho & Certified & Certified & \\
Montana & Certified & Certified & \\
Nevada & NV033 & NV052 & CA084 \\
Washington & & & Certified
\end{tabular}


CLIENT: Bechtel Nevada

PROJECT NAME: NA

PROJECT NUMBER: 2151

TEST: $\quad$ Total Extractable Petroleum Hydrocarbons by EPA Method 8015M, July 1992

METHOD: EPA 8015M

MATRIX: Solid

ANALYST: Suzanne

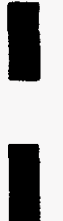

CLIENT

SAMPLE ID

2-300/B3@10'

2-300/B3@.15'

2-300/B3@20'

2-300/B3@25'

\begin{tabular}{ccr}
$\begin{array}{c}\text { SAMPLE } \\
\text { DATE }\end{array}$ & $\begin{array}{c}\text { NEL } \\
\text { SAMPLE ID }\end{array}$ & $\begin{array}{r}\text { RESULT } \\
\mathrm{mg} / \mathrm{kg}\end{array}$ \\
\hline $2 / 9 / 98$ & L9802126-01 & ND
\end{tabular}

2/9/98 L9802126-02

2/9/98 L9802126-03

2/9/98 L9802126-04
ND

ND

ND

C.R. $\frac{\begin{array}{c}\text { Reporting } \\ \text { Limit }\end{array}}{10 . \mathrm{mg} / \mathrm{kg}}$

10. $\mathrm{mg} / \mathrm{kg}$

10. $\mathrm{mg} / \mathrm{kg}$

$10 . \mathrm{mg} / \mathrm{kg}$

\section{Surrogate}

Recovery* EXTRACTED ANALYZED

$65 \% \quad 2 / 13 / 98$

$64 . \%$

$2 / 13 / 98$

$2 / 18 / 98$

$67 \% \quad 2 / 13 / 98$

$2 / 18 / 98$

$55 \% \quad 2 / 13 / 98$

$2 / 18 / 98$

Note: The reporting limit for Oil Range Organics in soil is $50 \mathrm{mg} / \mathrm{kg}$.

QUALITY CONTROL DATA (Total for Gas and Diesel Range):

Sample ID

Blank, 980213tphs -BLK

LCS, 980213tphs - LCS
Result Acceptable Range Surrogate Recovery* Sample Number

$\begin{array}{llllll}\mathrm{ND} & < & 10 . \mathrm{mg} / \mathrm{kg} & 87 & \% & \text { NA } \\ 98 \% & 55 & -102 \% & 86 & \% & \text { NA }\end{array}$

ND - Not Detected

*Surrogate used was Octacosane, acceptance limits 53-111\%.

This report shall not be reproduced except in full, without the written approval of the laboratory. 
SAMPLE DELIVERY GROUP: V357

LABORATORY: NEL

FINAL REPORT RECEIVED: 4/16/98

DATE REVIEWED: 4/22/98

TPH - DIESEL:

MATRIX: SOIL
CLIENT: RP - JERRY BONN

REVIEWED BY:

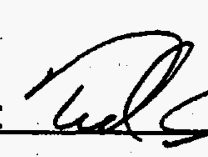

\section{ARE TPH DIESEL DATA ACCEPTABLE: YES.}

ARE CRITERIA MET

1. QC SAMPLES ACCEPTABLE

2. MATRIX SPIKE ACCEPTABLE

3. METHOD BLANK ACCEPTABLE

4. HOLDING TIMES ACCEPTABLE

$\frac{\frac{\text { YES }}{\text { N/A }}}{\frac{\text { YES }}{\text { YES }}}$

a. Date Sampled:

b. Date ASL Received:

c. Date Contract Lab Received:

d. Date Extracted:

e. Date Analyzed:
\# DAYS

$\underline{2 / 9 / 98}$

N/A

2/13/98

2/13/98

2/18/98
0

N/A

4

4

5
ACCEPTABLE
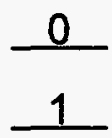

5

14

40

5. CALCULATIONS ACCEPTABLE:

6. CORRECT CONC. UNITS USED:

7. FORMS ACCEPTABLE:

8. CHAIN-OF-CUSTODY AGREES:

$\frac{\frac{\text { YES }}{\text { YES }}}{\frac{\text { YES }}{\text { YES }}}$

COMMENTS: Method associated quality assurance and control criteria were met. All samples were reported as non detects at the Reporting Limit $10 \mathrm{mg} / \mathrm{kg}$. Prelimiveng dats were fued. to the cleent on $2 / 25 / 98$. 


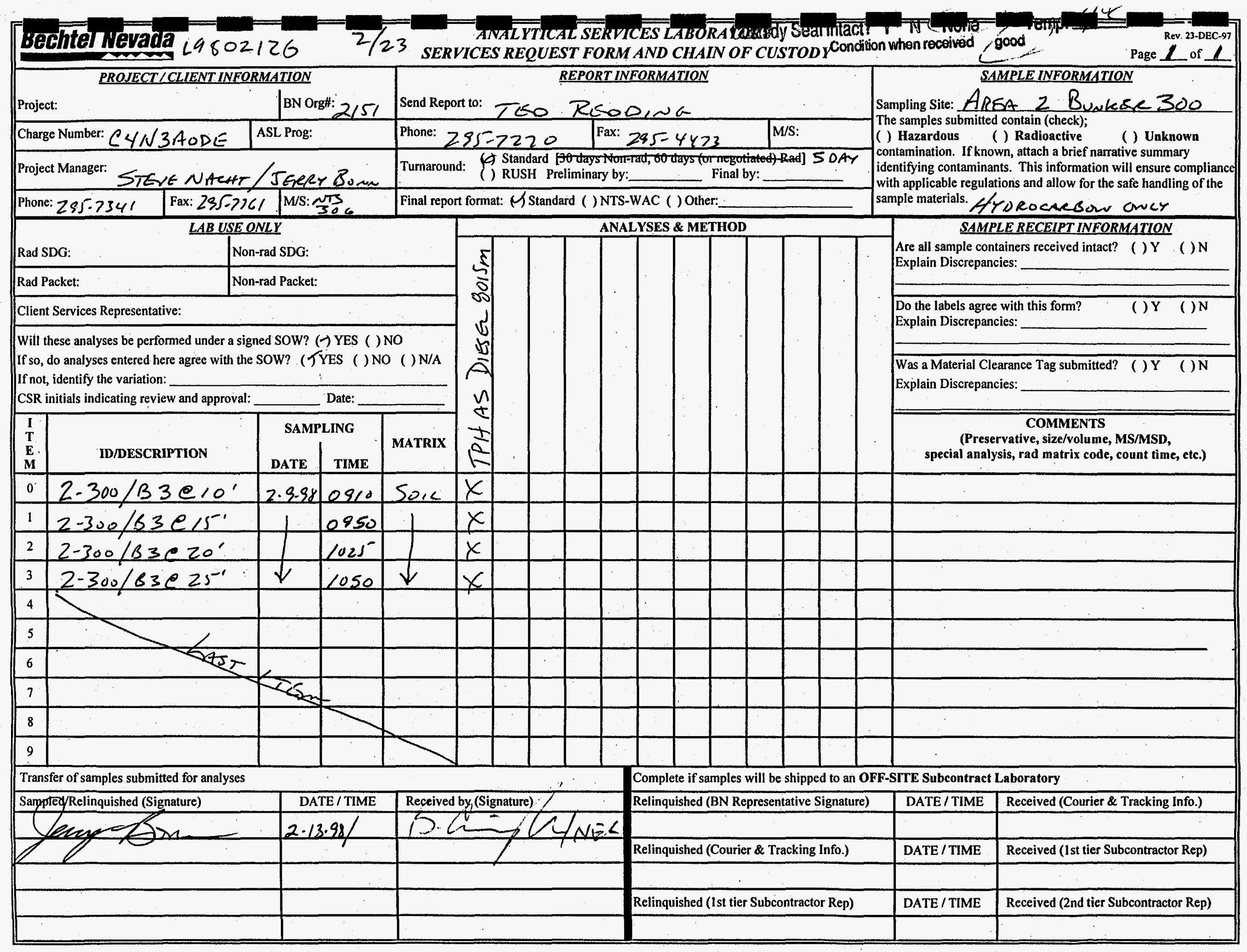




\section{DISTRIBUTION LIST}




\section{Controlled Copies}

Paul Liebendorfer

Bureau of Federal Facilities

Division of Environmental Protection

333 W. Nye Lane, Room 13B

Carson City, NV 89706-0866

Donald Garrepy

1

Bureau of Federal Facilities

Division of Environmental Protection

555 E. Washington, Suite 4300

Las Vegas, NV 89101

Sabrina Bonnell

Environmental Restoration Division

DOE/Nevada Operations Office

P. O. Box 98518, M/S 505

\section{Uncontrolled Copies}

Janet Appenzeller-Wing

Environmental Restoration Division

DOE/Nevada Operations Office

P. O. Box 98518, M/S 505

Las Vegas, NV 89193-8518

Clayton Barrow

Environmental Restoration Division

DOE/Nevada Operations Office

P. O. Box 98518, M/S 505

Las Vegas, NV 89193-8518

DOE Public Reading Room

P.O. Box 98521, M/S NLV040

Las Vegas, NV 89193-8521

DOE/Nevada Operations Office

Technical Information Resource Center

P.O. Box 98518, M/S 505

Las Vegas, NV 89193-8518 


\section{DISTRIBUTION LIST (continued)}

\section{Uncontrolled Copies}

U. S. Department of Energy,

Office of Scientific and Technical Information

P. O. Box 62

Oak Ridge, TN 37831

Correspondence Control

Bechtel Nevada

P. O. Box 98521, M/S NLV008

Las Vegas, NV 89193-8521

Jerry Bonn

Bechtel Nevada

P. O. Box 98521, M/S NTS306

Las Vegas, NV 89193-8521

David Cowser

Bechtel Nevada

P. O. Box 98521, M/S NLV082

Las Vegas, NV 89193-8521

Steve Nacht

Bechtel Nevada

P. O. Box 98521, M/S NTS306

Las Vegas, NV 89193-8521 